Provided for non-commercial research and education use. Not for reproduction, distribution or commercial use.

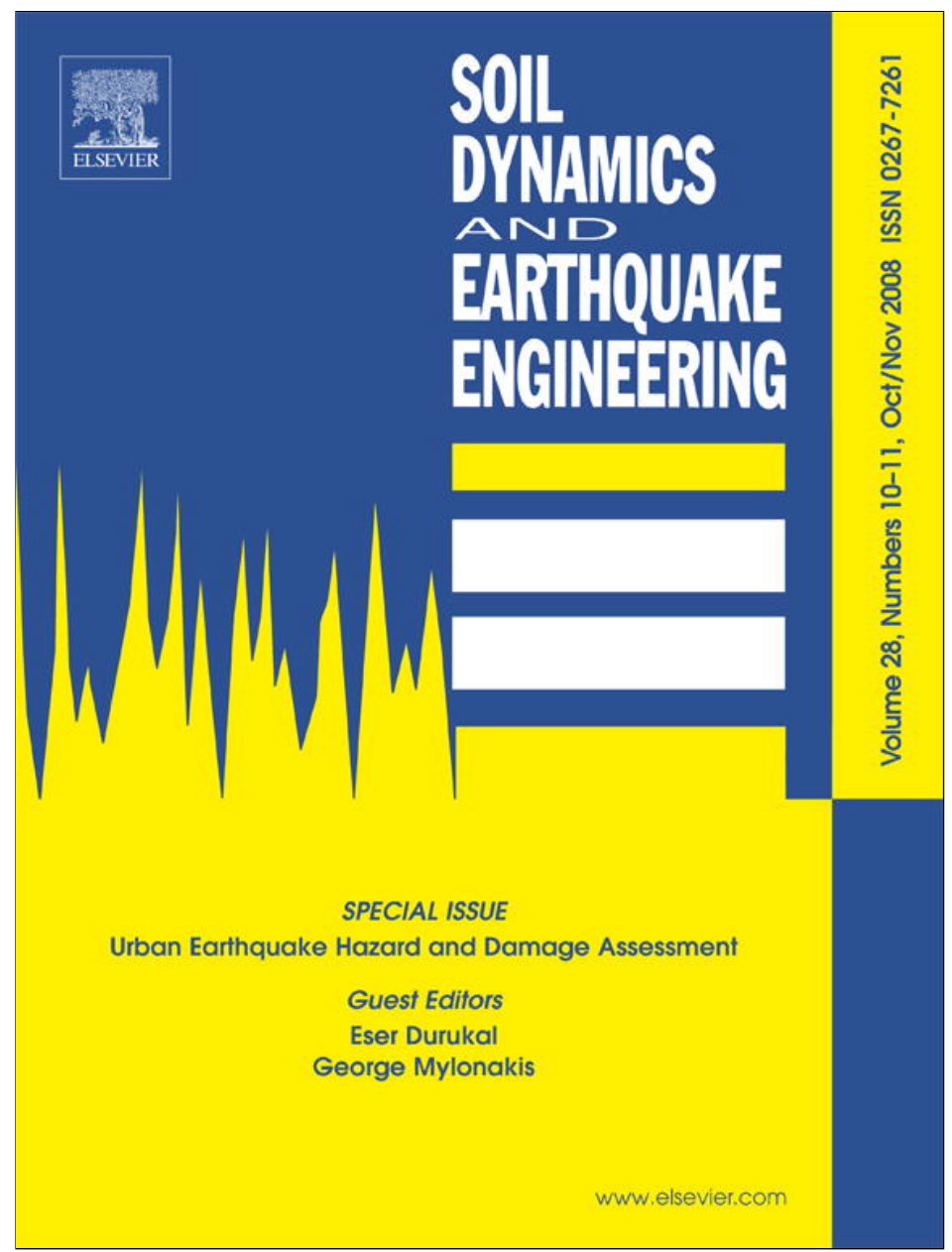

This article appeared in a journal published by Elsevier. The attached copy is furnished to the author for internal non-commercial research and education use, including for instruction at the authors institution and sharing with colleagues.

Other uses, including reproduction and distribution, or selling or licensing copies, or posting to personal, institutional or third party websites are prohibited.

In most cases authors are permitted to post their version of the article (e.g. in Word or Tex form) to their personal website or institutional repository. Authors requiring further information regarding Elsevier's archiving and manuscript policies are encouraged to visit:

http://www.elsevier.com/copyright 


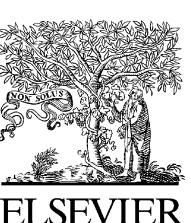

\title{
Seismic damage evaluation in urban areas using the capacity spectrum method: Application to Barcelona
}

\author{
Alex H. Barbat ${ }^{\mathrm{a}, *}$, Luis G. Pujades ${ }^{\mathrm{b}}$, Nieves Lantada ${ }^{\mathrm{b}}$ \\ a Department of Structural Mechanics, Civil Engineering School, Technical University of Catalonia, Edificio C1, Campus Norte UPC, \\ Jordi Girona 1-3, 08034 Barcelona, Spain \\ ${ }^{\mathrm{b}}$ Department of Geotechnical Engineering and Geosciences, Civil Engineering School, Technical University of Catalonia, Edificio D2, \\ Campus Norte UPC, Jordi Girona 1-3, 08034 Barcelona, Spain
}

Conceptual aspects related to seismic vulnerability, damage and risk evaluation are discussed first, together with a short review of the most widely used possibilities for seismic evaluation of structures. The capacity spectrum method and the way of obtaining seismic

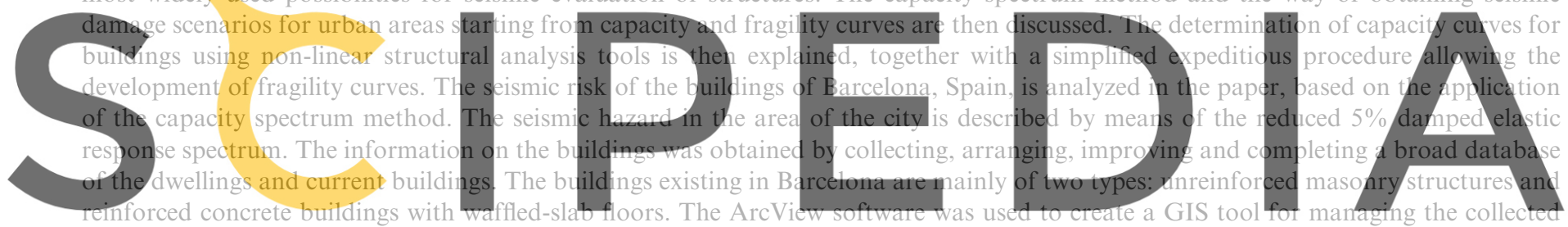
information in order to develop seismic risk scenarios. This study shows that the vulnerability of the buildings is significant in Barcelona

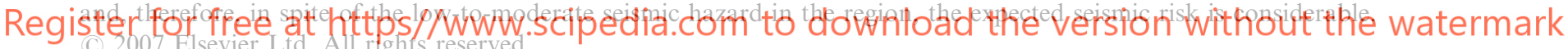

Keywords: Seismic hazard; Seismic vulnerability; Seismic risk; Damage evaluation; Capacity spectrum; Fragility curve; Damage probability matrix; Risk scenario

\section{Introduction}

The major part of losses due to earthquakes has its origin in the deficient seismic behavior of structures. In spite of the advances of research in earthquake engineering in general and on seismic design codes in particular, catastrophic losses have occurred recently in many countries in the world even in those where earthquake engineering studies are priority tasks. The aim of risk studies is to estimate and map the expected damage in structures due to a specified earthquake at a territorial

\footnotetext{
*Corresponding author. Tel.: + 34934016496 ; fax: +34934011048 .

E-mail addresses: alex.barbat@upc.edu (A.H. Barbat), lluis.pujades@upc.edu (L.G. Pujades).
}

scale, for instance, an urban area. There are a number of methodologies to estimate the vulnerability, damage and risk in seismic areas (e.g. Ref. [1-3]) and all of them have difficulties arising basically from the lack or low quality of available data when they are applied in low-to-moderate seismic areas.

Damage probability matrices, vulnerability functions and fragility curves, obtained from structural damages observed during earthquakes, were the preferred tools in the seismic risk studies in the past [1,4-6]. A complete observed damage database would be necessary for applying such approaches; however, this is only possible in highseismicity areas where properly performed post-earthquake surveys are available. In areas where the data for the existing building typologies and for the seismic intensities are limited or incomplete, local expert opinion has been 
used to support or completely replace probabilistic processing of the observed data [2,7]. Building modeling and non-linear structural analysis are other methods to stand in for the shortage of data [8-10]. In areas without any available damage database, the information obtained in other similar areas was applied, but at the same time using an expert judgment [11]. To complete the earthquake damage information in areas with lack of data, Monte Carlo simulation procedures have been used in the past [12,4-6]. Accordingly, the probabilistic analysis of computer-generated structural responses, obtained by using nonlinear analysis procedures of representative buildings, has provided fragility curves, damage probability matrices and vulnerability functions.

There are certain aspects of the seismic damage evaluation of an urban area which have to be nointed out: (1) uncertainties are high in each step of seismic risk evaluation, particularly in the evaluation of the seismic hazard in low-to-moderate seismic areas and of the vulnerability of existing buildings. It is not the purpose of this paper to perform a probabilistic study in the strict sense, but to perform analyses based on average or most likely values. (2) For management purposes, risk requires a multidisciplinary evaluation that takes into accoun not only the expected physical damage, the number and type of casualties or also the conditions related to soci resitience, which favor the indirect resilence which far physical risk of urban area (3) Th damage,
nic losses, but
y and lack of
when a hazard
aper, we study
he most recent trends in the field of vulnerability evaluation for risk

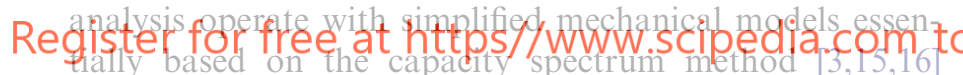
and this will be the method used in this paper. The method permits evaluating the expected seismic performance of structures by comparing, in spectral coordinates, their seismic capacity with the seismic demand, described by acceleration-displacement response spectra (ADRS) adequately reduced in order to take into account the inelastic behavior [17,18].

The seismic risk of the city of Barcelona (Spain) is analyzed in this paper. This city is located in an area of low-to-moderate seismic hazard [19], but its buildings have a high vulnerability. Most of the residential buildings have been designed and built without the consideration of any earthquake resistant criterion and many of their particular features, typical for the constructive techniques of the city, have been identified as potential damage sources. Detailed information on their design has been obtained through the years by collecting, arranging, improving and completing the database of the housings and buildings of the city. It is important to note that $97 \%$ of the housings in Barcelona are unreinforced masonry and reinforced concrete with waffled-slab floors buildings. In order to develop damage and risk scenarios, capacity spectra and fragility curves have been developed and are used to simulate earthquake risk scenarios.

\section{Capacity spectrum-based method}

The capacity spectrum method has been used in this article to estimate the expected performance of the buildings of Barcelona when subjected to selected earthquakes scenarios. A summary of displacement-based methods of earthquake damage estimation can be found in Calvi et al. [20].

In this article, the earthquake ground motion is modeled by means of $5 \%$ damped elastic response spectra in ADRS format according to the procedure given by Faccioli [21]. Deterministic and probabilistic hazard scenarios are considered.

Capacity curves mainly depend on the structural design and on the construction practice. Reliable structural models have been used, allowing calculation of capacity curves which consider the constructive peculiarities of the existing buildings. A non-linear macro-element model, representative of a whole masonry panel, proposed by Gambarotta and Lagomarsino [22], has been used to model the unreinforced masonry buildings of Barcelona. This model permits representing, with a limited number of degrees of freedom, the two main masonry failure modes, which are based on bending-rocking and shear-sliding mechanisms. It is one of the few existing models describing the seismic behavior of

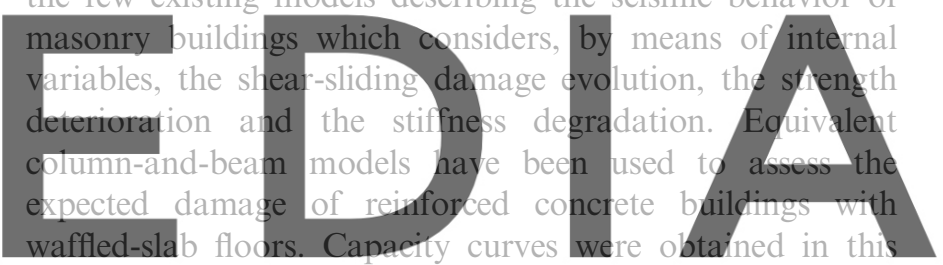

case by using the computer code RUAUMOKO [23]

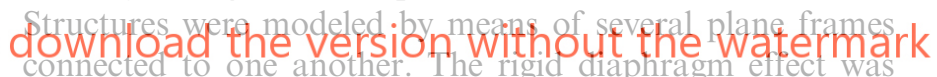

considered by constraining the nodes belonging to the same storey. The obtained capacity curves have been represented in the same spectral acceleration $\left(S_{\mathrm{a}}\right)$-spectral displacement (Sd) domain as the demand spectrum. Finally, these curves have been described in their bilinear form defined by yielding $\left(D_{\mathrm{y}}, A_{\mathrm{y}}\right)$ and ultimate $\left(D_{\mathrm{u}}, A_{\mathrm{u}}\right)$ points. Crossing the demand and capacity spectra, the performance point is determined and thus the expected spectral displacement. The performance point is calculated by using the iterative method (procedure A) of ATC-40 [24].

In order to analyze the seismic damage, we considered for the buildings in Barcelona five damage states ds: none, slight, moderate, severe and complete. For unreinforced masonry buildings and reinforced concrete buildings with waffled-slab floors, these damage states have the same meaning as in HAZUS (2002) but the complete damage grade includes the very heavy damage and the destruction states (grades 4 and 5) corresponding to the 1998 European Macroseismic Scale, EMS'98 [25]. A weighted average damage index, $\mathrm{DS}_{\mathrm{m}}$, can be calculated as

$\mathrm{DS}_{\mathrm{m}}=\sum_{i=0}^{4} \mathrm{ds}_{i} P\left[\mathrm{ds}_{i}\right]$ 
where $\mathrm{ds}_{i}$ takes the values $0,1,2,3$ and 4 for the damage states $i$ considered in the analysis and $P\left[\mathrm{ds}_{i}\right]$ are the corresponding occurrence probabilities. $\mathrm{DS}_{\mathrm{m}}$ is close to the most likely damage state of the structure. Table 1 shows the most probable damage grade as a function of the average damage index.

This damage index is useful for mapping and analyzing damage distributions by using a single parameter. Of course, alternative maps may plot the spatial distribution of the probability of occurrence of a specified damage state $\mathrm{ds}_{i}$, that is $P\left[\mathrm{ds}_{i}\right]$.

Fragility curves define the probability that the expected global damage $d$ of a structure exceeds a given damage state $\mathrm{ds}_{i}$, as a function of a parameter quantifying the severity of the seismic action. Here, this parameter is the spectral displacement $\mathbf{S} d$. Thus, for each damage state, the corresponding fragility curve is completely defined by plotting $P\left[d \geqslant \mathrm{ds}_{i}\right]$ as ordinate and the spectral displacement $\mathrm{Sd}$ as abscissa. If we assume that fragility curves follow a lognormal probability distribution, they are completely defined by only two parameters, which are the mean spectral displacement $\overline{\mathrm{Sd}}_{\mathrm{ds}_{i}}$ and the corresponding standard deviation $\beta_{\mathrm{ds}}$. Thus, for a given damage state $\mathrm{ds}_{i}$, a fragility curve is well described by the following lognormal

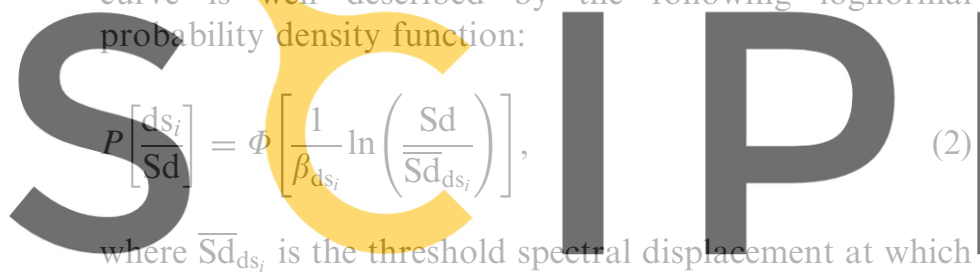
the probability of the damage state $\mathrm{ds}_{i}$ is $50 \%, \beta_{\mathrm{ds}}$ is the

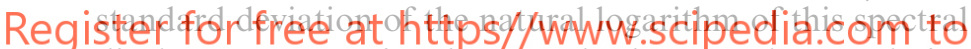
displacement, $\Phi$ is the standard normal cumulative distribution function and $\mathrm{Sd}$ is the spectral displacement.

Fragility curves can be obtained in a simplified way starting from the bilinear representation of the capacity curves. Fig. 1 and Table 2 show how the thresholds $\overline{\mathrm{Sd}}_{\mathrm{ds}_{i}}$ are obtained in this case in function of the yielding displacement $D_{\mathrm{y}}$ and the ultimate displacement $D_{\mathrm{u}}$ of the structure.

Concerning $\beta_{\mathrm{ds}}$, it is well known that the expected seismic damage in buildings follows a binomial probability distribution [25]. Therefore, it is assumed that at the $\overline{\mathrm{Sd}}_{\mathrm{ds}}$ threshold, the probability of this damage state is $50 \%$. Table 3 shows the cumulative expected probabilities of all the damage states when a particular damage state probability is fixed to $50 \%$ and a binomial probability

Table 1

Damage states and mean damage index values

\begin{tabular}{ll}
\hline Mean damage index intervals & More probable damage state \\
\hline $0-0.5$ & No damage \\
$0.5-1.5$ & Slight damage \\
$1.5-2.5$ & Moderate damage \\
$2.5-3.5$ & Severe damage \\
$3.5-4.0$ & Complete damage \\
\hline
\end{tabular}

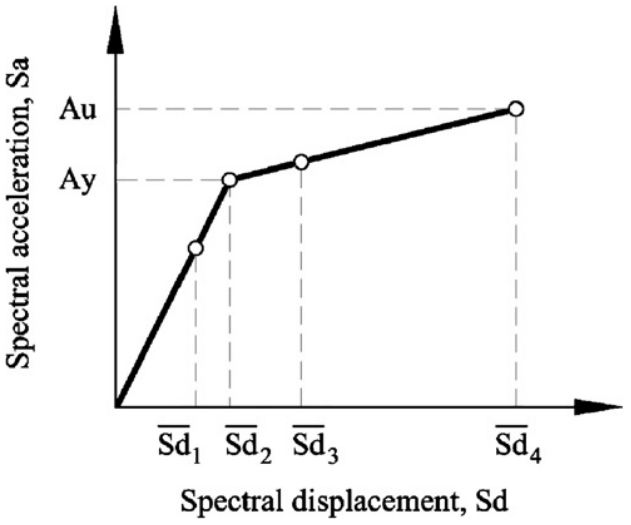

Fig. 1. Damage state thresholds from capacity spectrum.

Table 2

Damage state thresholds (see Fig. 1)

\begin{tabular}{|c|c|}
\hline$\overline{\mathrm{Sd}}_{1}=0.7 D_{\mathrm{y}}$ & Slight \\
\hline$\overline{\mathrm{Sd}}_{2}=D_{\mathrm{y}}$ & Moderate \\
\hline$\overline{\mathrm{Sd}}_{3}=D_{\mathrm{y}}+0.25\left(D_{\mathrm{u}}-D_{\mathrm{y}}\right)$ & Severe \\
\hline$\overline{\mathrm{Sd}}_{4}=D_{\mathrm{u}}$ & Complete \\
\hline
\end{tabular}

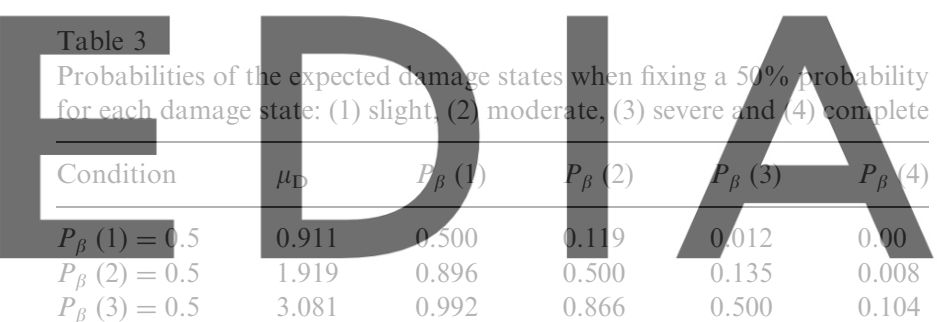

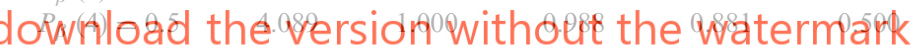

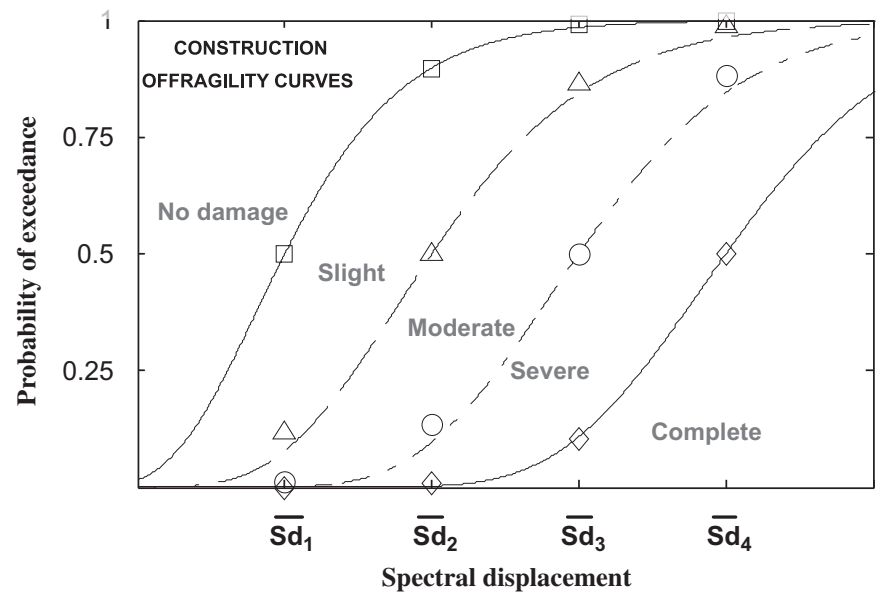

Fig. 2. Example of fragility curves construction.

distribution is assumed. The parameter $\mu_{\mathrm{D}}$ controls the assumed binomial probability distribution.

Finally, the function expressed by Eq. (2) is fitted to the obtained points by means of a least-square criterion. Fig. 2 shows an example of fragility curves obtained by using this method. 
Finally, for each hazard scenario and for each class of building, damage probability matrices can be obtained by entering with the spectral displacement corresponding to the performance point into the corresponding fragility curves.

\section{Description of the urban area of Barcelona}

\subsection{The building types}

The most representative type of buildings of the central part of Barcelona is the unreinforced masonry one, whose large number greatly influences the overall seismic vulnerability of the city. Only a part of the structures of this area are made of reinforced concrete, substituting demolished unreinforced masonry buildings, but they are found in a significant number in other more recently built districts of the city. The most emblematic and representative district of Barcelona is the "Eixample", in the central part of the city, designed in the middle of the nineteenth century and special attention has been paid in this study to the seismic risk evaluation of this area. Covering about 750 ha, it consists of square blocks sizing about $113 \mathrm{~m} \times 113 \mathrm{~m}$. These blocks are perfectly aligned and are beveled in their vertices

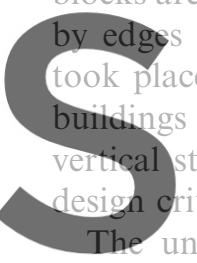
of about $20 \mathrm{~m}$. The cons
between 1860 and 1950 ,
for each block, which w
atic loads, without any c
eria.
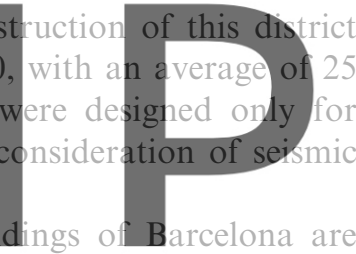
tall and have openings of considerable size in their walls,

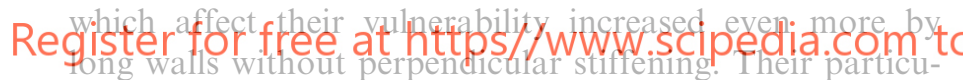

lar features, typical for the constructive techniques of the city at that time, have been identified as potential damage sources. As an example, the floors of these unreinforced masonry buildings are made of wooden, steel or precast concrete beams with small ceramics vaults in between, according to the building period, showing a poor stiffness both to bending moment and to axial forces. Another example is that almost all of these buildings have two soft storeys, due to the greater height of their first two floors. Furthermore, cast iron columns were used in many cases instead of masonry walls at the base and ground floors, reducing even more their lateral stiffness, because their upper and lower edges are not perfectly clamped. Similar masonry buildings can also be found in many other European and Mediterranean cities. In some of them, certain measures of seismic protection have been applied in the past, but there are also many buildings in such poor conditions that they have to be classified in the highest vulnerability class of the European Macroseismic Intensity Scale, EMS-98 [25].

Since the middle of the twentieth century, the number of reinforced concrete buildings increased significantly in Barcelona, becoming nowadays the most frequent typology for new buildings. Most of the reinforced concrete buildings of Barcelona are not moment resisting frames, but they consist of columns and slabs in their waffled-slab floors version, which is a structural type not adequate for seismic areas due to their low ductility. Most of them also have a soft first storey. The Spanish code limits their ductility factor to 2, while earthquakes like that of Kokaeli, Turkey, 1999, have dramatically shown the high seismic vulnerability of this kind of buildings. In the seismic areas of Europe, the seismic design of reinforced concrete buildings varies extremely and structures show a large variation of earthquake resistance. Accordingly, the EMS98 scale [25] assigns a very wide range of vulnerability to the framed reinforced concrete buildings used in Europe, which covers the whole vulnerability range from buildings without earthquake resistant design to buildings design with high-level seismic codes. In an extreme case, their vulnerability can be comparable with that of low-quality unreinforced brick masonry buildings. The reinforced concrete buildings of Barcelona fall within the high vulnerability part of the EMS-98 scale, for which significant damage for relatively low seismic intensities is expected.

In general, the buildings of Barcelona are part of aggregates, forming building blocks. In the past, designers,

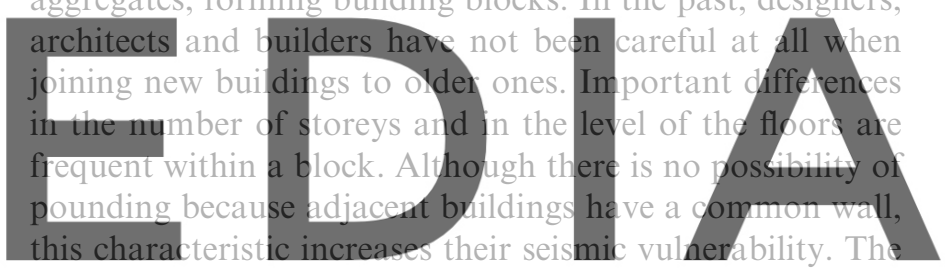
seismic analysis of a whole block is a complex problem

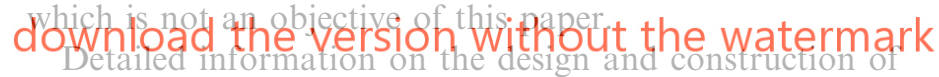

the buildings of Barcelona has been obtained through the years by collecting, arranging, improving and completing the database of the housings and buildings of the city. Three main information sources were used in obtaining data for the risk assessment at urban scale: (1) a territorial information system [26], (2) a file with the construction year of each building, and (3) a file containing information about the building types. The territorial information system contains the most important data, namely the cadastre information. The total number of cadastre units or lots in the city is 80,715 and they may contain a building or may be empty. This information was used to obtain the geometry and the core features of the buildings of the studied area, like perimeters and numbers of storeys of each built lot. A set of blocks composes the so-called small statistical zones, which are used for administrative purposes and are the basis for the census. These census zones, numbering 248, have been used to map risk scenarios; a relatively small number of them make up a neighborhood, whose total number is 38 , and a small number of neighborhoods make up a district whose total number is 10 .

According to the official statistics of Barcelona corresponding to the year 2001 [27], Barcelona has about 1.566 
millions inhabitants, 700,000 housings and 69,000 buildings, with an average of about 2.24 inhabitants in each. The Municipality of Barcelona provided the cadastre database, which is well described in the report Infocca [26], and detailed information concerning the age and typology of the buildings. The collected data allowed complete characterization of the geometrical features and geographical location together with the type and year of construction of about 63,000 buildings (more than 91\% of the total number of buildings), which mainly correspond to residential buildings. For the others, that is, about 6000 buildings, there is a lack of information about one or more of the mentioned characteristics. There are 60,653 unreinforced masonry and reinforced concrete buildings, which represent the $96.3 \%$ of the total number of residential buildings and only these have been included in the simulations performed in this study.

Fig. 3 shows the age distribution of the buildings as a function of the constructive periods in Spain that have been defined based on earthquake-resistant considerations. It can be seen that almost the $80 \%$ of the building stock of Barcelona was constructed prior to the first Spanish Seismic Code [28]. Fig. 4 shows the building typology distribution. Table 4 describes these building types. These

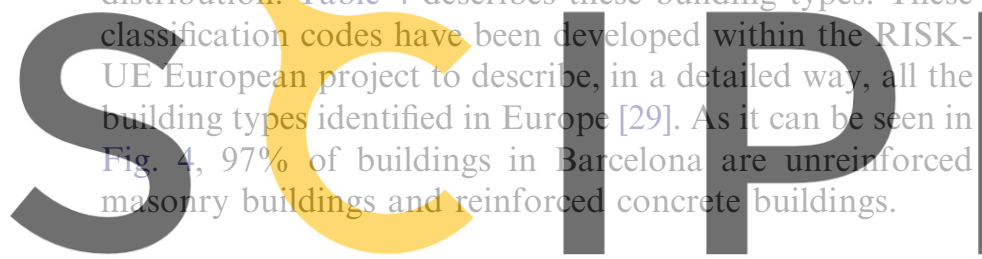

Register for free at https//www.sciperdia.g.eom to d

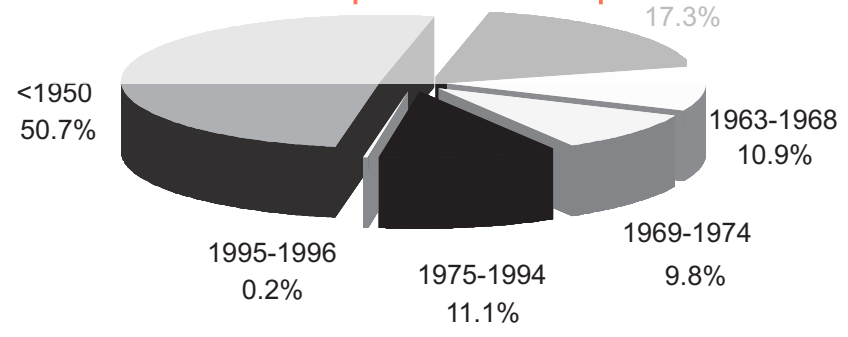

Fig. 3. Distribution of buildings by age.

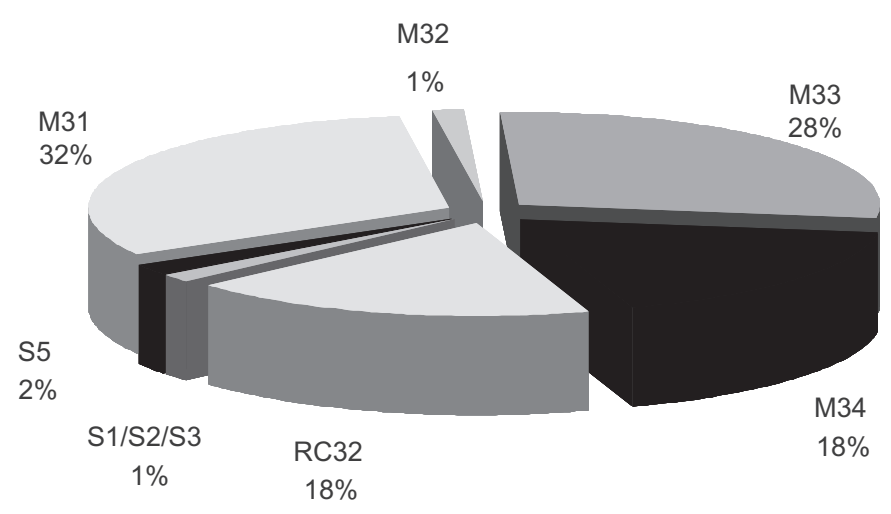

Fig. 4. Distribution of the buildings by typology.
Table 4

Building types in Barcelona

Code Building description

M31 Unreinforced masonry buildings (UMB) with wooden floors.

M32 UMB with masonry vaults.

M33 UMB with steel beams and masonry vaults.

M34 UMB with reinforced concrete (RC) beams and masonry vaults.

RC32 RC buildings with irregular structural system, irregular infill and soft/weak storey.

S1 Steel buildings with moment resisting frames.

S2 Steel buildings with braced frames.

S3 Steel buildings with frames with unreinforced masonry infill walls.

S5 Steel and RC composite buildings.

\subsection{Seismic hazard}

Barcelona, city located in the Northeastern part of Spain, has a low-to-moderate seismicity and weak tectonic motions. Deterministic and probabilistic hazard scenarios have been developed by the geological survey of Catalonia [30-33] following the guidelines of the RISK-UE project ([21]; see also Refs. [34,35]). The seismic action is defined in terms of elastic response acceleration spectra. The deterministic magnitude-distance scenario corresponds to a

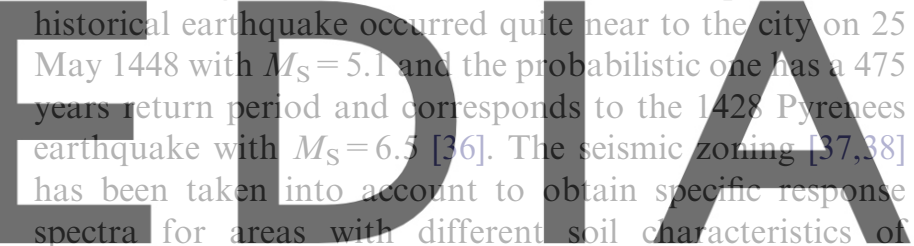

Barcelona. Fig. 5 shows the four main seismic zones of

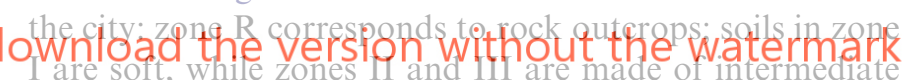
soils. Typical shear-wave velocities for these zones are 800 , 225, 394 and $405 \mathrm{~m} / \mathrm{s}$, respectively.

A simplified analytical equation based on the Eurocode EC8 has been used to fit average response spectra:

$$
S_{\mathrm{a}}(T)= \begin{cases}a_{\mathrm{g}}\left[1+\frac{T}{T_{\mathrm{B}}}\left(B_{\mathrm{C}}-1\right)\right] & 0 \leqslant T \leqslant T_{\mathrm{B}}, \\ a_{\mathrm{g}} B_{\mathrm{C}} & T_{\mathrm{B}} \leqslant T \leqslant T_{\mathrm{C}}, \\ a_{\mathrm{g}}\left(\frac{T_{\mathrm{C}}}{T}\right) B_{\mathrm{C}} & T_{\mathrm{C}} \leqslant T \leqslant T_{\mathrm{D}}, \\ a_{\mathrm{g}}\left(\frac{T_{\mathrm{C}} T_{\mathrm{D}}}{T^{2}}\right) B_{\mathrm{C}} & T_{\mathrm{D}} \leqslant T \leqslant 4 \mathrm{~s},\end{cases}
$$

where $S_{\mathrm{a}}(T)$ is the spectral acceleration; $T$ is the period; $a_{\mathrm{g}}$ is the peak ground acceleration; $B_{\mathrm{C}}$ is an amplification factor defined as $S_{a_{\max }} / a_{\mathrm{g}} ; T_{\mathrm{B}}$ and $T_{\mathrm{C}}$ are the limits of the constant acceleration interval; and $T_{\mathrm{D}}$ defines the beginning of the constant displacement section.

Fig. 6 shows the smoothed response spectra for the four soil types, both for the deterministic and probabilistic cases. The differences between the probabilistic and deterministic response spectra are due the fact that PSHA-derived spectrum includes the strong influence of the variability in the ground motion prediction equation 
whereas the deterministic case corresponds to the median ground motion for the given seismic hazard scenario $[39,40]$. Table 5 contains the parameters of the smoothed spectra according to Eq. (3) $[30,32]$.

\section{Structural capacity of the buildings of Barcelona}

An important objective of this paper was to produce building-by-building risk scenarios for Barcelona, which required the seismic characterization of about 60,653 residential buildings. It was decided to adopt a simplified

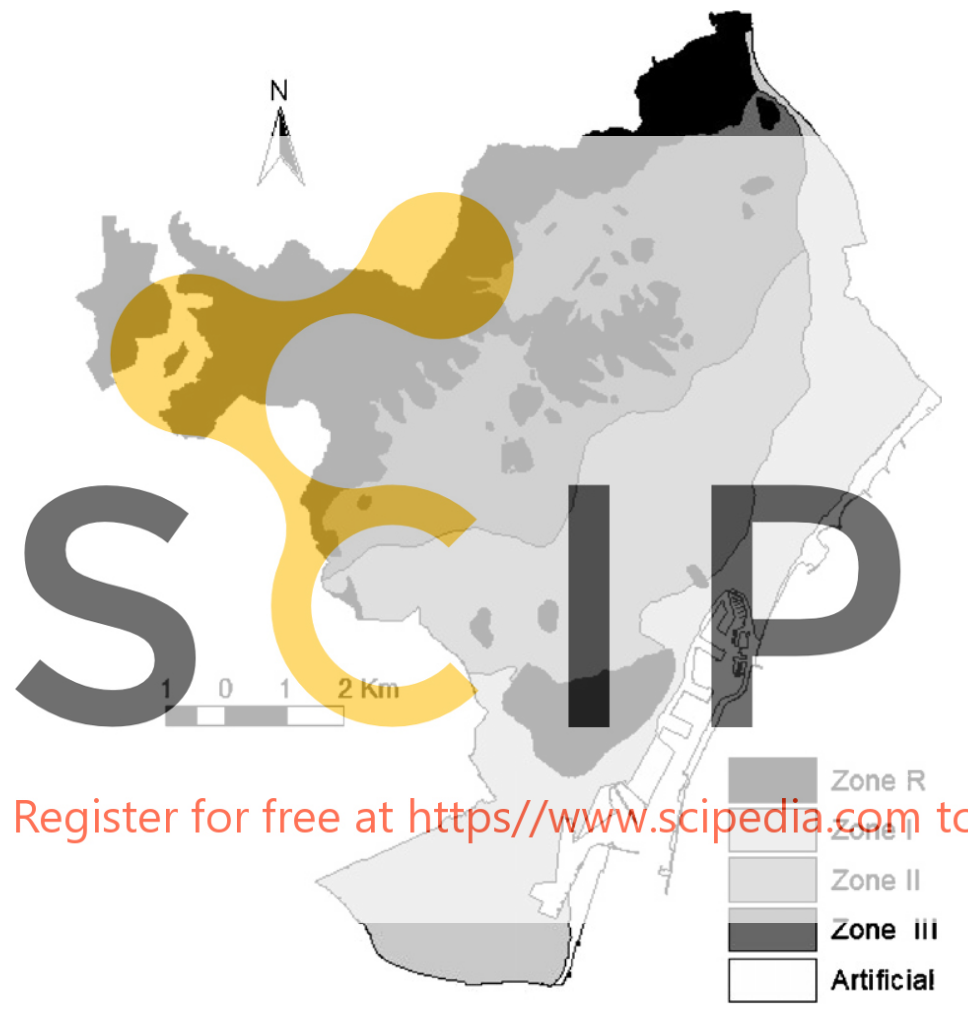

Fig. 5. Seismic zonation of Barcelona [37,38].

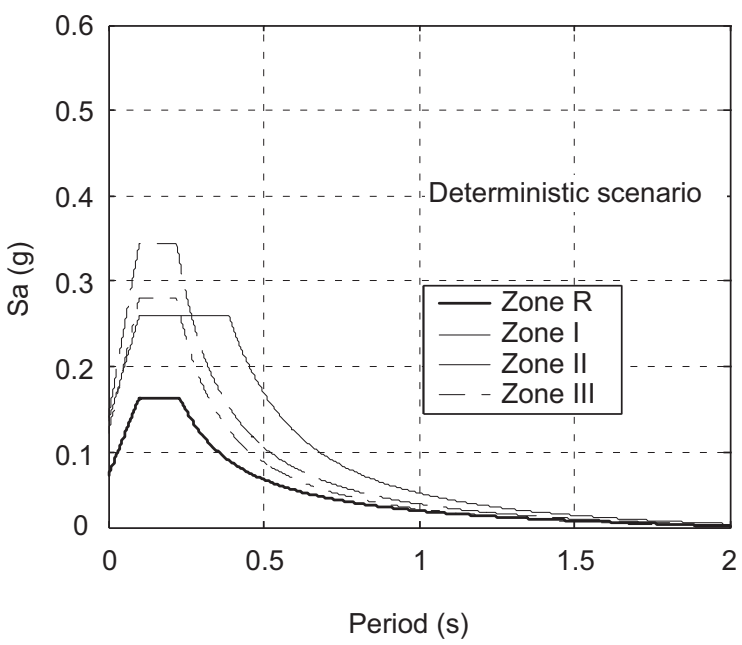

building typology matrix with only six models, which reasonably represents the wide number of buildings of the city. Selected, representative, existing buildings have been then analyzed by using simplified structural analysis models but adequately describing their seismic behavior. The seismic performance of a building can be characterized by its capacity spectrum obtained by means of a pushover analysis [24], modeled in its bilinear form.

Detailed structural plans have been used to model representative buildings for low-rise (two storeys, $5.2 \mathrm{~m}$ tall) mid-rise (five storeys, $15.8 \mathrm{~m}$ tall) and high-rise (eight storeys, $24.0 \mathrm{~m}$ tall) reinforced concrete buildings. Capacity curves were obtained by performing non-linear static analyses using the 2D version of the computer code RUAUMOKO [23]. Structures were modeled by means of several plane frames connected one to other. The rigid diaphragm effect was considered by constraining the nodes belonging to the same storey. High-rise and mid-rise buildings have a rectangular floor size of $25.65 \mathrm{~m} \times 21.90 \mathrm{~m}$ while the low-rise one has a $13.6 \mathrm{~m} \times 13.6 \mathrm{~m}$ floor area. The following mean mechanical properties have been assumed: concrete compression strength $f_{\text {ck }}=20 \mathrm{MPa}$, steel yield stress $f_{\mathrm{y}}=510 \mathrm{MPa}$, elastic modulus $E_{\mathrm{c}}=30 \mathrm{GPa}$, and shear modulus $G=12.5 \mathrm{GPa}$.

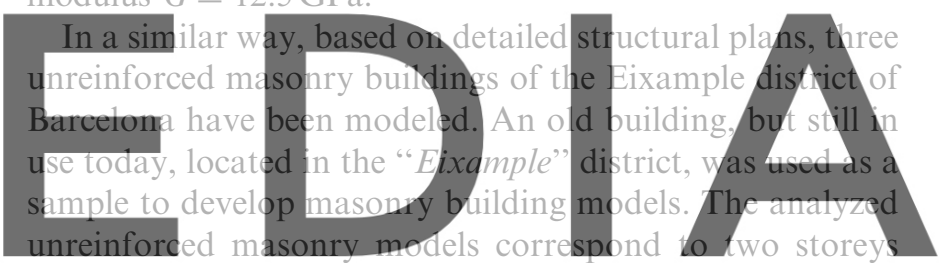

(low-rise), four storeys (mid-rise) and six storeys (high-rise) duildinfo of tharcelopsio Bothithe midth and hater riserk different height $(17 \mathrm{~m}$ and $24 \mathrm{~m}$ ). The low-rise building has a $7.3 \mathrm{~m} \times 9.3 \mathrm{~m}$ in floor and is $6.65 \mathrm{~m}$ tall. This last case corresponds to single-family houses of the residential areas of Barcelona. All the analyses have been performed with TreMuri program [41], a useful tool to study the non-linear

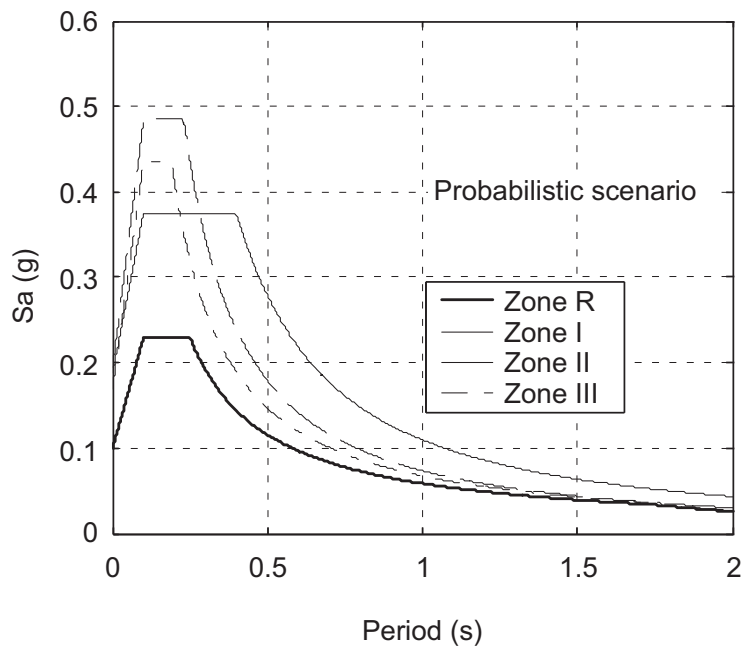

Fig. 6. Smoothed 5\% damped response spectra for the deterministic (left) and probabilistic (right) scenarios [31]. 
Table 5

Parameters for the 5\% damped elastic response spectra for the deterministic and probabilistic scenarios (see Eq. (3)) [30]

\begin{tabular}{|c|c|c|c|c|c|c|c|c|}
\hline & \multicolumn{4}{|c|}{ Deterministic scenario } & \multicolumn{4}{|c|}{ Probabilistic scenario } \\
\hline & Zone R & Zone I & Zone II & Zone III & Zone R & Zone I & Zone II & Zone III \\
\hline$a_{\mathrm{g}}\left(\mathrm{cm} / \mathrm{s}^{2}\right)$ & 71 & 133 & 138 & 120 & 98 & 184 & 190 & 166 \\
\hline$T_{\mathrm{B}}(\mathrm{seg})$ & 0.1 & 0.1 & 0.1 & 0.1 & 0.1 & 0.1 & 0.1 & 0.1 \\
\hline$T_{\mathrm{C}}(\mathrm{seg})$ & 0.23 & 0.39 & 0.22 & 0.22 & 0.25 & 0.40 & 0.23 & 0.19 \\
\hline$T_{\mathrm{D}}(\mathrm{seg})$ & 1.75 & 2.30 & 2.20 & 2.00 & 1.75 & 2.85 & 2.21 & 1.77 \\
\hline$B_{\mathrm{C}}$ & 2.26 & 1.91 & 2.45 & 2.29 & 2.29 & 2.0 & 2.50 & 2.57 \\
\hline $\operatorname{RMS} S_{\mathrm{a}}(\mathrm{g})$ & 0.01 & 0.03 & 0.03 & 0.05 & 0.01 & 0.03 & 0.04 & 0.06 \\
\hline $\operatorname{RMS~} S_{\mathrm{d}}(\mathrm{cm})$ & 0.08 & 0.12 & 0.11 & 0.14 & 0.07 & 0.19 & 0.19 & 0.18 \\
\hline
\end{tabular}

Table 6

Yield and ultimate capacity for reinforced concrete (RC) and unreinforced masonry (M) buildings

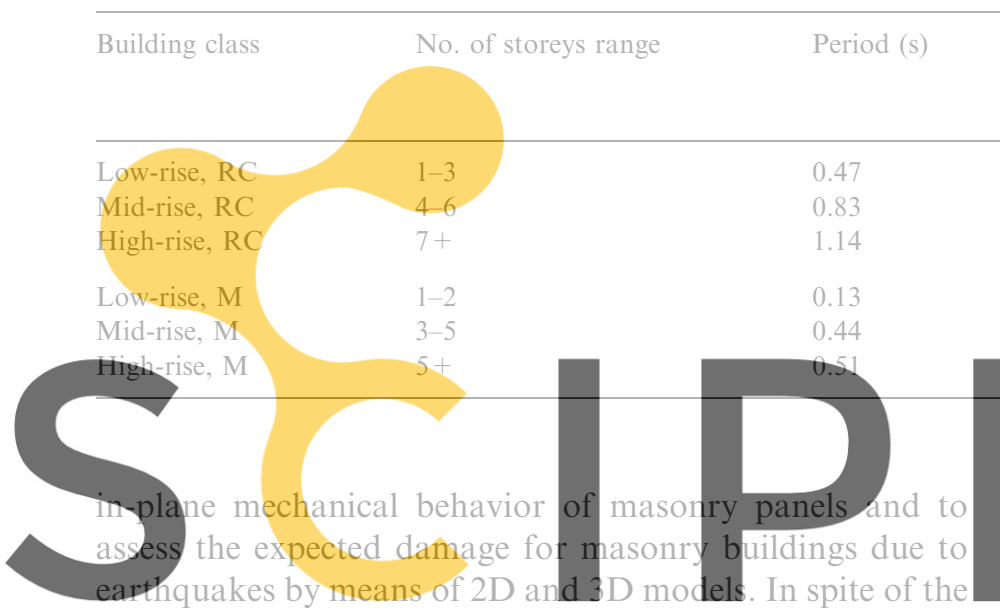

local flexural behavior of floors and walls, the out-of-plane

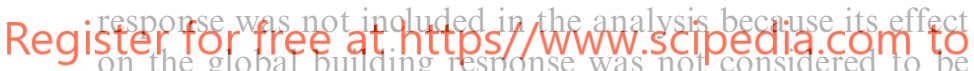

significant in this case, in which vertical and horizontal

structural elements are not properiy connected. The use of these tools guaranteed the computation of fragility curves and damage probability matrices for more than $95 \%$ of the residential building stock of the city, allowing developing representative risk scenarios which was the main goal of the study.

The highest expected period of the residential buildings existing in Barcelona is about one second and it corresponds to high-rise reinforced concrete buildings. As capacity curves are based on the assumption that the response of the structure is well represented by the fundamental mode of vibration, they describe adequately the seismic behavior of buildings with a fundamental period lower than $1 \mathrm{~s}$ [24]. Consequently, for the purpose of this study, which is the calculation of seismic risk scenarios for the whole city, capacity curves, in spite of their limitations, provide a reasonably good structural damage description for the residential buildings of Barcelona.

Pushover analyses allowed the capacity curves for each building class to be determined and, starting from these curves, capacity spectra have been obtained [24]. Table 6 shows the fundamental period and the yield and ultimate capacity points defining the bilinear capacity spectra for

\begin{tabular}{|c|c|c|c|}
\hline \multicolumn{2}{|c|}{ Yield capacity } & \multicolumn{2}{|c|}{ Ultimate capacity } \\
\hline$D_{\text {y }}(\mathrm{cm})$ & $A_{\mathrm{y}}(\mathrm{g})$ & $D_{\mathrm{u}}(\mathrm{cm})$ & $A_{\mathrm{u}}(\mathrm{g})$ \\
\hline 0.70 & 0.13 & 5.24 & 0.14 \\
\hline 1.42 & 0.08 & 5.11 & 0.12 \\
\hline 1.89 & 0.06 & 4.67 & 0.08 \\
\hline 0.27 & 0.65 & 1.36 & 0.56 \\
\hline 0.63 & 0.13 & 2.91 & 0.12 \\
\hline & & 2.61 & 0.08 \\
\hline
\end{tabular}

Fig. 7 shows the bilinear capacity spectra for reinforced

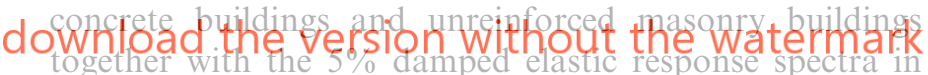
ADRS format for the deterministic and probabilistic scenarios. Observe that the crossing points are performance points only when they belong to the linear branch of the capacity curves. But even when they are on the nonlinear branch, a graphic estimate of the performance point can be visualized by taking into account the equivalent linear displacement method. This fact becomes important when evaluating damage by using fragility curves because it greatly influences on the damage probability matrices. A significant ductility can be observed for mid-rise and high-rise masonry buildings. This fact should be related to an excessive slenderness of these buildings and also to the failure criterion used in the pushover analysis performed by means of the model proposed by Gambarotta and Lagomarsino [22], adequate to the masonry buildings of the type existing in Barcelona. It can be also seen in Fig. 7 how the capacity decreases with the height of the building both for masonry and for RC buildings. The capacity spectrum for low-rise masonry buildings shows high stiffness and strength. In fact, this type of building, representative for a number of one-family houses, mainly located in the residential districts of the city, is completely different from the mid- and high-rise masonry buildings. 

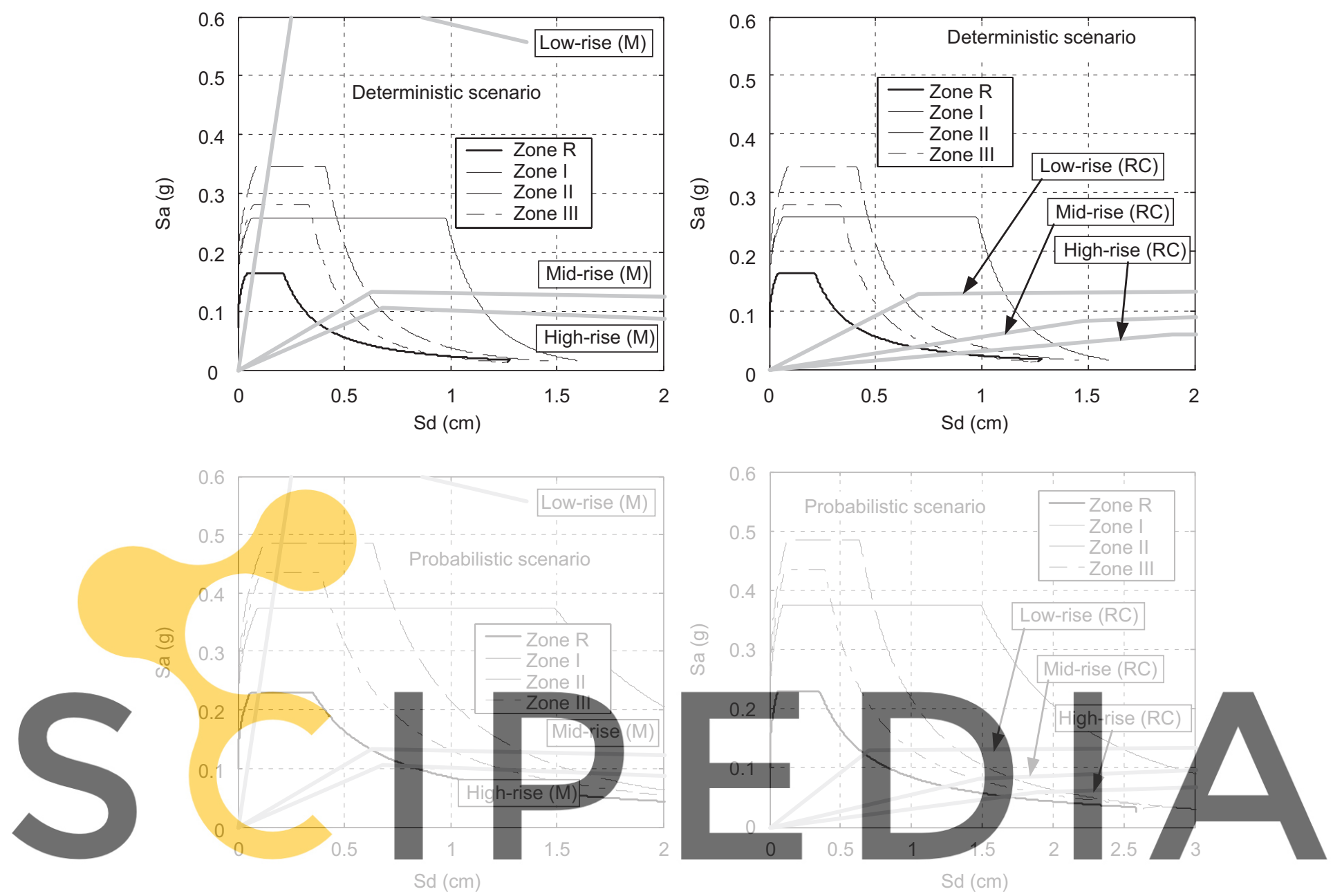

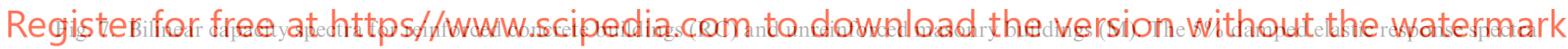
in ADRS format are also shown for the deterministic and probabilistic cases.

\section{Fragility curves and damage probability matrices for the buildings of Barcelona}

Specific fragility curves have been developed for both masonry and reinforced concrete buildings of Barcelona. Fig. 8 shows the obtained curves. Table 7 shows the values of the parameters $\overline{\mathrm{Sd}}_{i}$ and $\beta_{i}$, where $i=1, \ldots, 4$, which define the corresponding cumulative lognormal distribution (see Eq. (2)). It can be observed that reinforced concrete buildings are more ductile than the masonry ones, showing a better seismic performance. For example, for mid-rise reinforced concrete buildings in Fig. 8, in case of a $4 \mathrm{~cm}$ spectral displacement, the expected probability for the complete damage state is about $30 \%$, but it is more than $60 \%$ for unreinforced masonry buildings. Fortunately, Barcelona is located in an area of low seismic hazard, but the analyses clearly point out the very high vulnerability of the buildings and, consequently, a significant probability of damage even in the case of a not too severe earthquake.

It is somewhat surprising that the obtained results show high expected seismic damage for relatively low spectral displacements. They indicate that the reinforced concrete buildings with waffled-slab floors are really weak. This is a reasonable result when taking into account the particular structural type described above. In any case, for each hazard scenario, damage probability matrices strongly depend on the spectral displacement of the performance point. Table 8 shows these matrices for the masonry buildings of Barcelona. Both scenarios, deterministic and probabilistic, are considered for the four seismic zones of the city and for the three building classes corresponding to low-rise, mid-rise and high-rise buildings. Similar matrices have been obtained for reinforced concrete buildings (see Table 9).

In Tables 8 and $9, \mathrm{DS}_{\mathrm{m}}$ is the weighted average damage state calculated by using Eq. (1), which can be considered close to the most likely damage state of the structure. These tables show how the expected damage for a relatively small earthquake can be relatively high. In the deterministic case (Table 8), for example, there is a probability of $0.281+$ $0.178=0.459$ that high-rise unreinforced masonry buildings located in zone II have a damage state between moderate and severe, due to the high vulnerability of this type of buildings. 

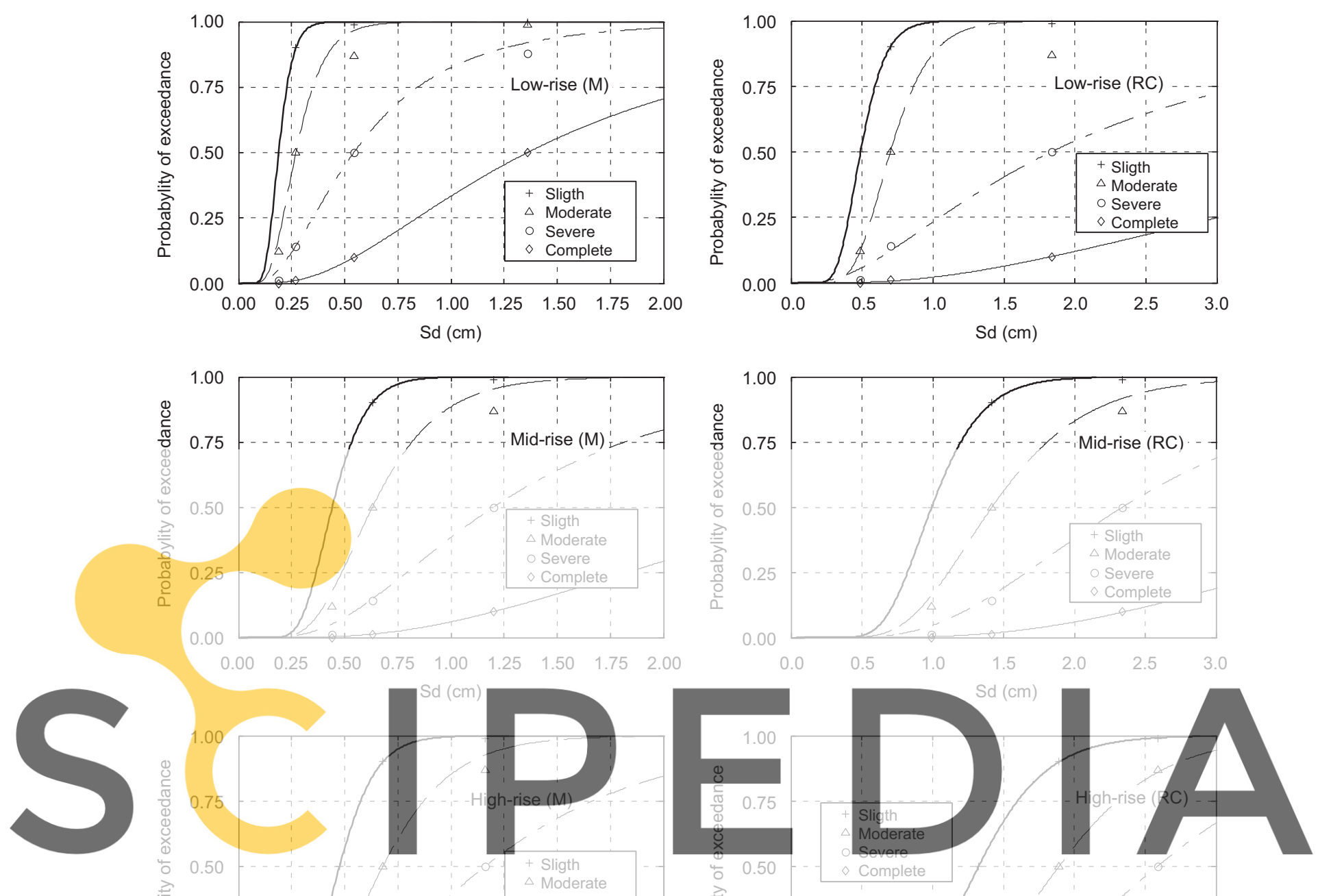

Register foc free at https//www.sciped tar.6em to downnload the version without the watermark
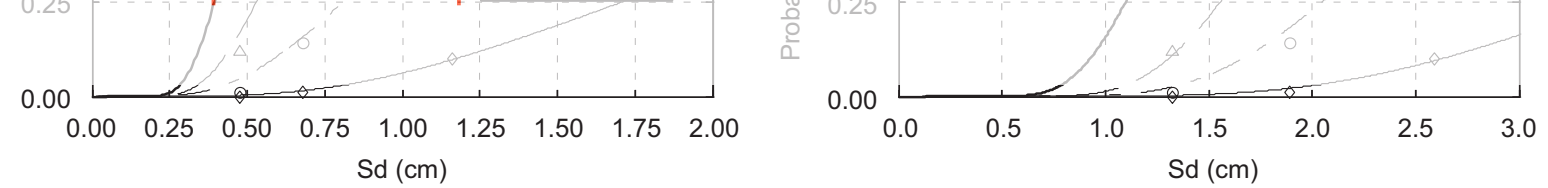

Fig. 8. Fragility curves for masonry (M) and reinforced concrete (RC) buildings.

Table 7

Parameters characterizing the fragility curves, for reinforced concrete buildings (RC) and unreinforced masonry buildings (M)

Building class Damage states thresholds

$\overline{\mathrm{Sd}}_{1}(\mathrm{~cm}) \beta_{1} \quad \overline{\mathrm{Sd}}_{2}(\mathrm{~cm}) \beta_{2} \quad \overline{\mathrm{Sd}}_{3}(\mathrm{~cm}) \beta_{3} \quad \overline{\mathrm{Sd}}_{4}(\mathrm{~cm}) \beta_{4}$

\begin{tabular}{lllllllll}
\hline Low-rise, RC & 0.49 & 0.28 & 0.70 & 0.37 & 1.84 & 0.82 & 5.24 & 0.83 \\
Mid-rise, RC & 0.99 & 0.28 & 1.42 & 0.36 & 2.34 & 0.50 & 5.11 & 0.61 \\
High-rise, RC & 1.33 & 0.28 & 1.89 & 0.29 & 2.59 & 0.34 & 4.68 & 0.45 \\
Low-rise, M & 0.19 & 0.28 & 0.27 & 0.37 & 0.54 & 0.54 & 1.36 & 0.72 \\
Mid-rise, M & 0.44 & 0.40 & 0.63 & 0.50 & 1.20 & 0.75 & 2.91 & 0.70 \\
High-rise, M & 0.46 & 0.30 & 0.68 & 0.65 & 1.68 & 0.65 & 2.61 & 0.65 \\
\hline
\end{tabular}

According to EMS-98 [25] and to the calculated damage probability matrices for masonry buildings of Table 8 , the vulnerability of most of the residential buildings of
Barcelona may be included in the vulnerability classes B and $\mathrm{C}$ in a scale ranging from $\mathrm{A}$ (very high) to $\mathrm{F}$ (very low). EMS-98 predicts significant damage for these buildings even for low macroseismic intensities like VI and V. Note that macroseismic scales are based on real damage data observed during past earthquakes, covering a wide period of time and a wide range of earthquake sizes and building classes. Mid-rise and high-rise RC buildings show a better seismic performance for the selected ground motion scenarios but the expected damage is greater for low-rise $\mathrm{RC}$ buildings.

\section{Risk scenarios for Barcelona}

Results for seismic risk scenarios simulated for Barcelona are shown in this section. Spatial convolution between seismic hazard and fragility, through damage probability 
Table 8

Damage probability matrices for masonry buildings for deterministic and probabilistic hazard scenarios

\begin{tabular}{|c|c|c|c|c|c|c|c|c|c|c|c|c|}
\hline \multirow[t]{3}{*}{ Zone } & \multicolumn{6}{|c|}{ Deterministic hazard scenario } & \multicolumn{6}{|c|}{ Probabilistic hazard scenario } \\
\hline & \multicolumn{5}{|c|}{ Damage state probabilities } & \multirow[t]{2}{*}{$\mathrm{DS}_{\mathrm{m}}$} & \multicolumn{5}{|c|}{ Damage state probabilities } & \multirow[t]{2}{*}{$\mathrm{DS}_{\mathrm{m}}$} \\
\hline & 0 & 1 & 2 & 3 & 4 & & 0 & 1 & 2 & 3 & 4 & \\
\hline \multicolumn{13}{|c|}{ Low-rise } \\
\hline I & 0.950 & 0.037 & 0.011 & 0.002 & 0.000 & 0.066 & 0.632 & 0.257 & 0.095 & 0.014 & 0.002 & 0.498 \\
\hline II & 0.737 & 0.189 & 0.063 & 0.009 & 0.001 & 0.349 & 0.287 & 0.416 & 0.249 & 0.042 & 0.006 & 1.065 \\
\hline III & 0.917 & 0.061 & 0.018 & 0.003 & 0.001 & 0.109 & 0.431 & 0.365 & 0.173 & 0.027 & 0.004 & 0.807 \\
\hline $\mathrm{R}$ & 1.000 & 0.000 & 0.000 & 0.000 & 0.000 & 0.001 & 0.981 & 0.013 & 0.004 & 0.002 & 0.000 & 0.025 \\
\hline \multicolumn{13}{|c|}{ Mid-rise } \\
\hline I & 0.003 & 0.166 & 0.399 & 0.353 & 0.079 & 2.339 & 0.000 & 0.032 & 0.322 & 0.453 & 0.193 & 2.807 \\
\hline II & 0.121 & 0.384 & 0.289 & 0.189 & 0.017 & 1.598 & 0.007 & 0.160 & 0.419 & 0.347 & 0.067 & 2.306 \\
\hline III & 0.273 & 0.364 & 0.215 & 0.139 & 0.009 & 1.247 & 0.029 & 0.270 & 0.395 & 0.271 & 0.035 & 2.012 \\
\hline $\mathrm{R}$ & 0.623 & 0.193 & 0.105 & 0.076 & 0.003 & 0.642 & 0.109 & 0.391 & 0.305 & 0.181 & 0.014 & 1.600 \\
\hline \multicolumn{13}{|c|}{ High-rise } \\
\hline I & 0.003 & 0.145 & 0.389 & 0.371 & 0.092 & 2.404 & 0.000 & 0.019 & 0.248 & 0.464 & 0.269 & 2.983 \\
\hline II & 0.135 & 0.388 & 0.281 & 0.178 & 0.018 & 1.556 & 0.002 & 0.133 & 0.385 & 0.381 & 0.099 & 2.441 \\
\hline III & 0.307 & 0.369 & 0.195 & 0.120 & 0.009 & 1.155 & 0.014 & 0.23 & 0.386 & 0.307 & 0.056 & 2.154 \\
\hline $\mathrm{R}$ & 0.647 & 0.205 & 0.086 & 0.059 & 0.003 & 0.566 & 0.632 & 0.257 & 0.095 & 0.014 & 0.002 & 0.498 \\
\hline
\end{tabular}

Zones corresponding to the seismic microzonation of the city: R, rocky outcrops and I, soft soils. Damage states: 0 , none; 1 , slight; 2 , moderate; 3 , severe; and 4 , complete. $\mathrm{DS}_{\mathrm{m}}$ : weighted mean damage state.

Table 9

Damage probability matrices for reinforced concrete buildings for deterministic and probabilistic hazard scenarios

\begin{tabular}{|c|c|c|c|c|c|c|c|c|c|c|c|c|}
\hline \multirow[t]{3}{*}{ Zone } & \multicolumn{6}{|c|}{ Deterministic hazard scenario } & \multicolumn{6}{|c|}{ Probabilistic hazard scenario } \\
\hline & \multicolumn{5}{|c|}{ Damage state probabilities } & \multirow[t]{2}{*}{$\mathrm{DS}_{\mathrm{m}}$} & \multicolumn{5}{|c|}{ Damage state probabilities } & \multirow[t]{2}{*}{$\mathrm{DS}_{\mathrm{m}}$} \\
\hline & 0 & 1 & 2 & 3 & 4 & & 0 & 1 & 2 & 3 & 4 & \\
\hline \multicolumn{13}{|c|}{ Low-rise } \\
\hline I & 0.020 & 0.280 & 0.450 & 0.220 & 0.030 & 1.960 & 0.020 & 0.240 & 0.450 & 0.250 & 0.040 & 2.050 \\
\hline II & 0.180 & 0.420 & 0.300 & 0.090 & 0.010 & 1.330 & 0.080 & 0.380 & 0.400 & 0.130 & 0.010 & 1.610 \\
\hline III & 0.420 & 0.340 & 0.170 & 0.070 & 0.000 & 0.890 & 0.200 & 0.400 & 0.310 & 0.080 & 0.010 & 1.300 \\
\hline $\mathrm{R}$ & 0.760 & 0.180 & 0.020 & 0.040 & 0.000 & 0.340 & 0.470 & 0.340 & 0.130 & 0.060 & 0.000 & 0.780 \\
\hline \multicolumn{13}{|c|}{ Mid-rise } \\
\hline I & 0.220 & 0.440 & 0.240 & 0.090 & 0.010 & 1.230 & 0.120 & 0.410 & 0.330 & 0.120 & 0.020 & 1.510 \\
\hline II & 0.680 & 0.230 & 0.060 & 0.030 & 0.000 & 0.440 & 0.430 & 0.370 & 0.150 & 0.040 & 0.010 & 0.830 \\
\hline III & 0.840 & 0.120 & 0.030 & 0.010 & 0.000 & 0.210 & 0.610 & 0.280 & 0.080 & 0.030 & 0.000 & 0.530 \\
\hline $\mathrm{R}$ & 0.920 & 0.060 & 0.010 & 0.010 & 0.000 & 0.110 & 0.670 & 0.240 & 0.070 & 0.020 & 0.000 & 0.440 \\
\hline \multicolumn{13}{|c|}{ High-rise } \\
\hline $\mathrm{I}$ & 0.480 & 0.340 & 0.080 & 0.080 & 0.020 & 0.820 & 0.290 & 0.420 & 0.140 & 0.110 & 0.040 & 1.190 \\
\hline II & 0.800 & 0.150 & 0.010 & 0.030 & 0.010 & 0.300 & 0.560 & 0.300 & 0.060 & 0.060 & 0.020 & 0.680 \\
\hline III & 0.920 & 0.060 & 0.020 & 0.000 & 0.000 & 0.100 & 0.700 & 0.220 & 0.030 & 0.040 & 0.010 & 0.440 \\
\hline $\mathrm{R}$ & 0.930 & 0.050 & 0.000 & 0.020 & 0.000 & 0.110 & 0.660 & 0.240 & 0.040 & 0.040 & 0.020 & 0.520 \\
\hline
\end{tabular}

Zones corresponding to the seismic microzonation of the city: R, rocky outcrops and I, soft soils. Damage states: 0 , none; 1 , slight; 2 , moderate; 3 , severe; 4, complete. $\mathrm{DS}_{\mathrm{m}}$ : weighted mean damage state.

matrices, allows estimating the spatial distribution of expected damage. Although damage is assessed building by building, we show damage results for the main administrative divisions of the city: districts, neighborhoods and census zones. The mean damage grade for the entire city is 0.86 for the deterministic scenario, with a standard deviation of 0.71 , while for the probabilistic case we obtained a mean damage grade of $1.51 \pm 0.87$ which respectively correspond to slight and moderate damage states according to Table 1 . 
Fig. 9 depicts the physical seismic risk scenario for the deterministic hazard case. Fig. 10 shows the scenarios for the probabilistic case. These scenarios are mapped for different administrative units of the city, namely: (a) districts, (b) neighborhoods and (c) census zones, thus allowing different resolution maps. Maps at district and neighborhood scales smooth the maps of census zones and they provide average information that is easier to analyze and interpret. Maps at census zones level are more detailed. They show greater resolution and are more useful, for instance, for preparedness, risk management and emergency planning.

The districts of Ciutat Vella (01) and Eixample (02) are the oldest in the city and they show the greatest expected damage. Ciutat Vella means Old City and it is the downtown of Barcelona, with the oldest buildings of the city, mainly masonry buildings. It is expected that Ciutat Vella would be the most damaged district in case of earthquake. Eixample means widening and this district includes the urban area designed and projected in the second half of the XIX century in order to plan and organize the growth of the city between Ciutat Vella and the near small towns or villages which give the names to another eight districts of the city (e.g. Gracia and SarriáSant Gervasi). The Eixample district was built between the end of the XIXth century and the beginning of the XXth century. In the deterministic case, the expected mean damage state for Ciutat Vella and Eixample districts are 1.77 and 1.16 , respectively. In the probabilistic case, these values are 2.49 and 1.9, respectively. Fig. 11 shows detailed, building-by-building, scenarios. In this figure, special and other types of buildings have been excluded from the damage analysis due to their negligible effect on the final damage scenarios.

Figs. 12 and 13 are supplementary examples of risk scenarios showing the probability of a given damage state; a

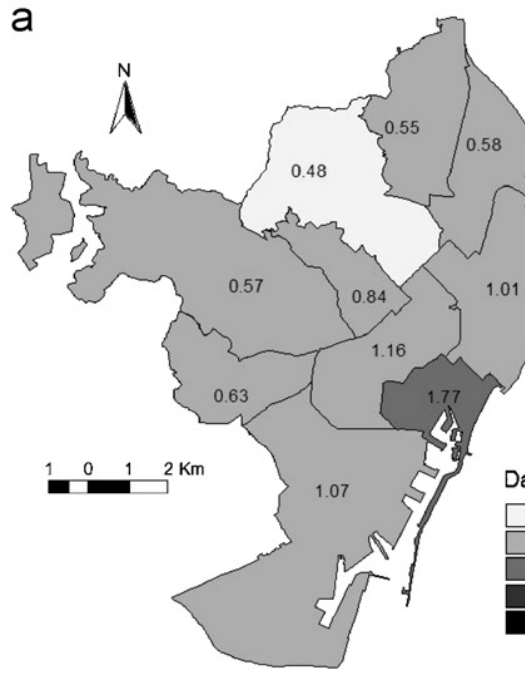

b
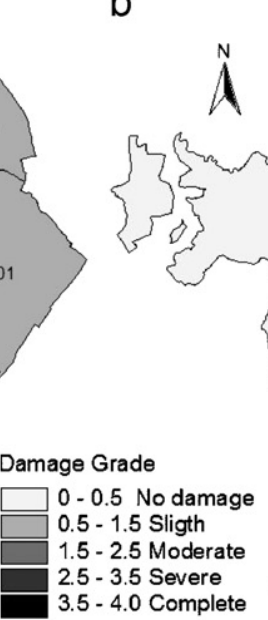

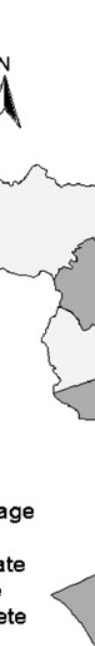

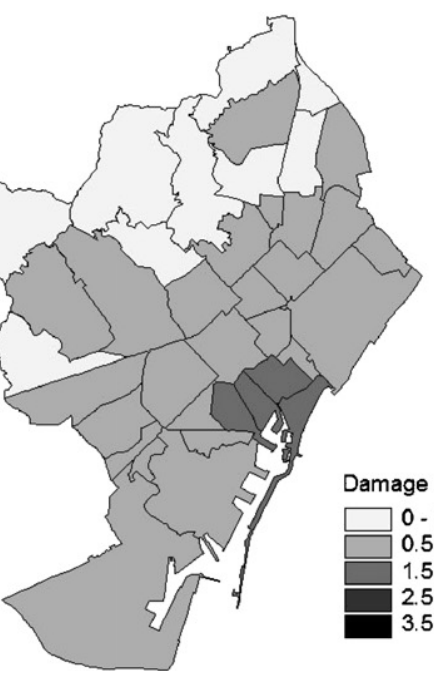

C
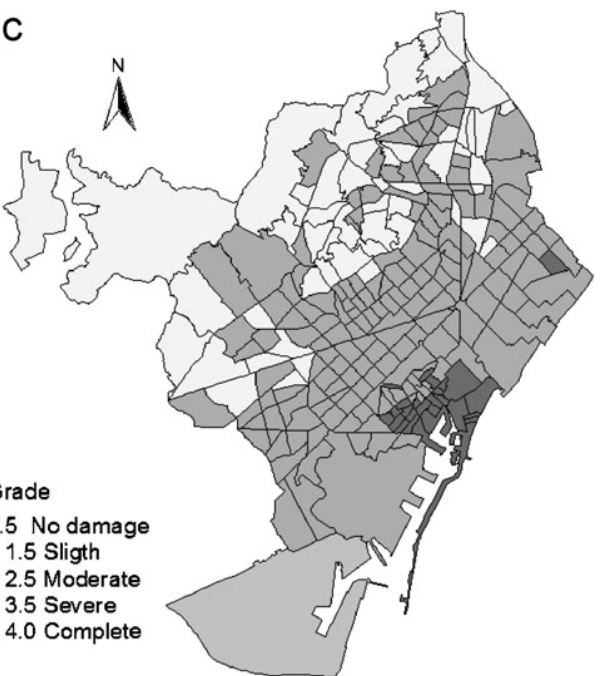

Grade 5. 1.5 Sligth

5 - 2.5 Moderate

$5-3.5$ Severe

-4.0 Complete

Fig. 9. Damage scenario corresponding to the deterministic hazard scenario: (a) districts, (b) neighborhoods and (c) census zones.

a

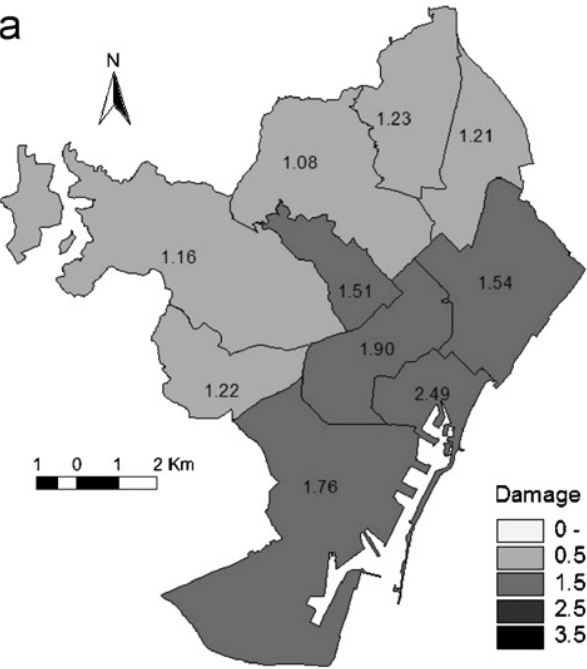

b
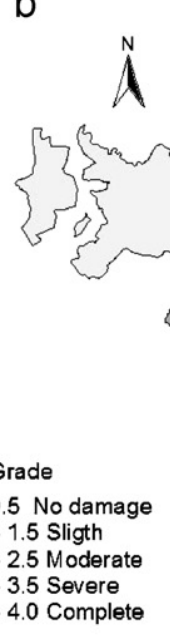

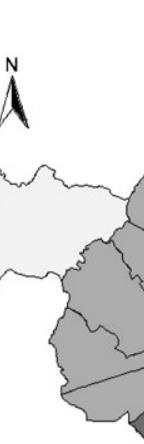

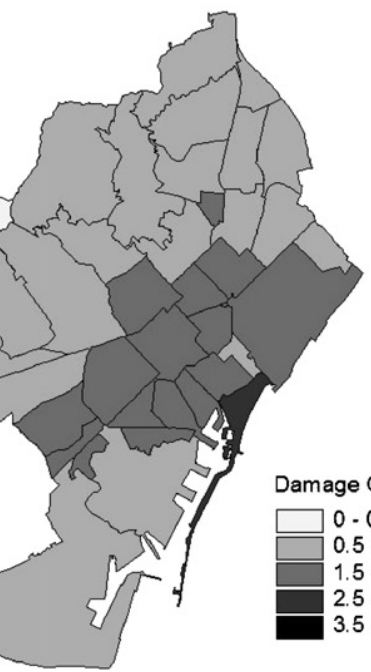

C

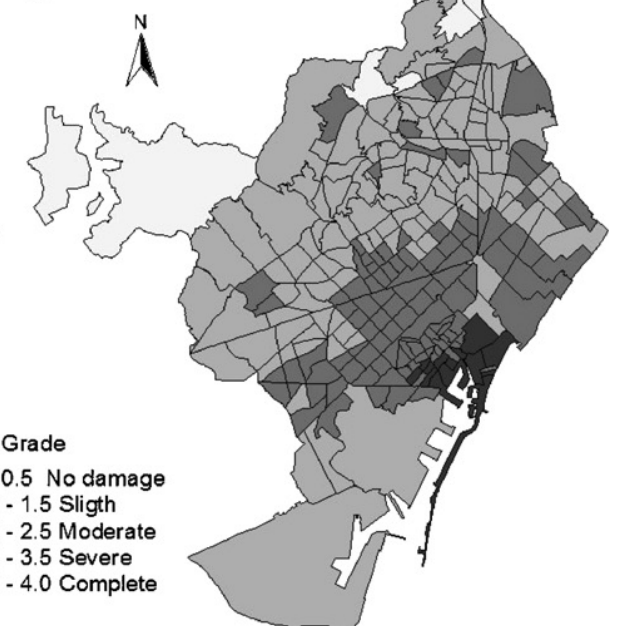

Fig. 10. Damage scenario corresponding to the probabilistic hazard scenario: (a) districts, (b) neighborhoods and (c) census zones. 
these figures display the probability distribution in the Ciutat Vella and the Eixample districts, respectively, for the moderate and severe damage states. Fig. 12 shows how the probabilistic scenario would produce a significant number of severe damaged buildings in the Ciutat Vella district, since about a half of its buildings show severe damage state probabilities in the range between $40 \%$ and $50 \%$. Fig. 13 shows how for the probabilistic earthquake in the Eixample district, most of the buildings attain significant probability for the severe damage state, namely in the probability range $30-40 \%$. It has to be noticed that more than $70 \%$ of the buildings in this district are old, unreinforced, high-rise masonry buildings and that all of them are located in the soil Zone II. Thus, according to the values in Table 8 , for the probabilistic case, the occurrence probability of the severe damage state is 0.381 , which is consistent with the probability distribution mapped in Fig. 13.

From Tables 8 and 9 and Figs. 9-13, it is followed that the probabilistic hazard scenario is more damaging than the deterministic one. This fact is reasonable according to the differences between the probabilistic and deterministic response spectra explained in Section 3.2. Sets of maps, like those in Figs. 9-13, have been developed for the entire city, districts, neighborhoods and census zones. In addition, it is possible to develop any type of detailed seismic risk scenario for any seismic hazard case.
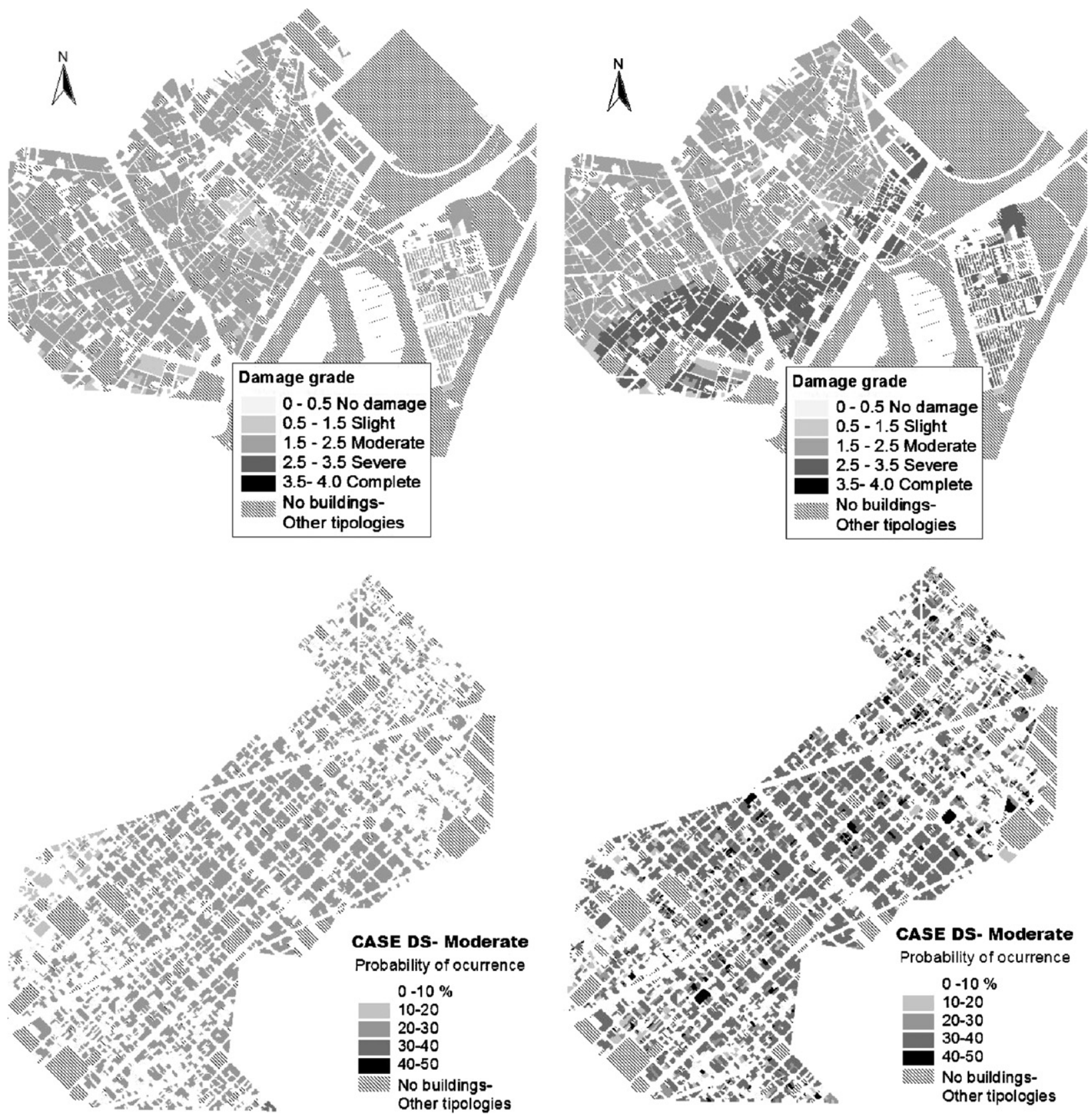

Fig. 11. Detailed damage scenarios, building by building, for Ciutat Vella (above) and Eixample (below) districts. Both deterministic (left) and probabilistic (right) seismic scenarios are shown. These two districts are where the expected damage is more important (see also Figs. 9 and 10). 

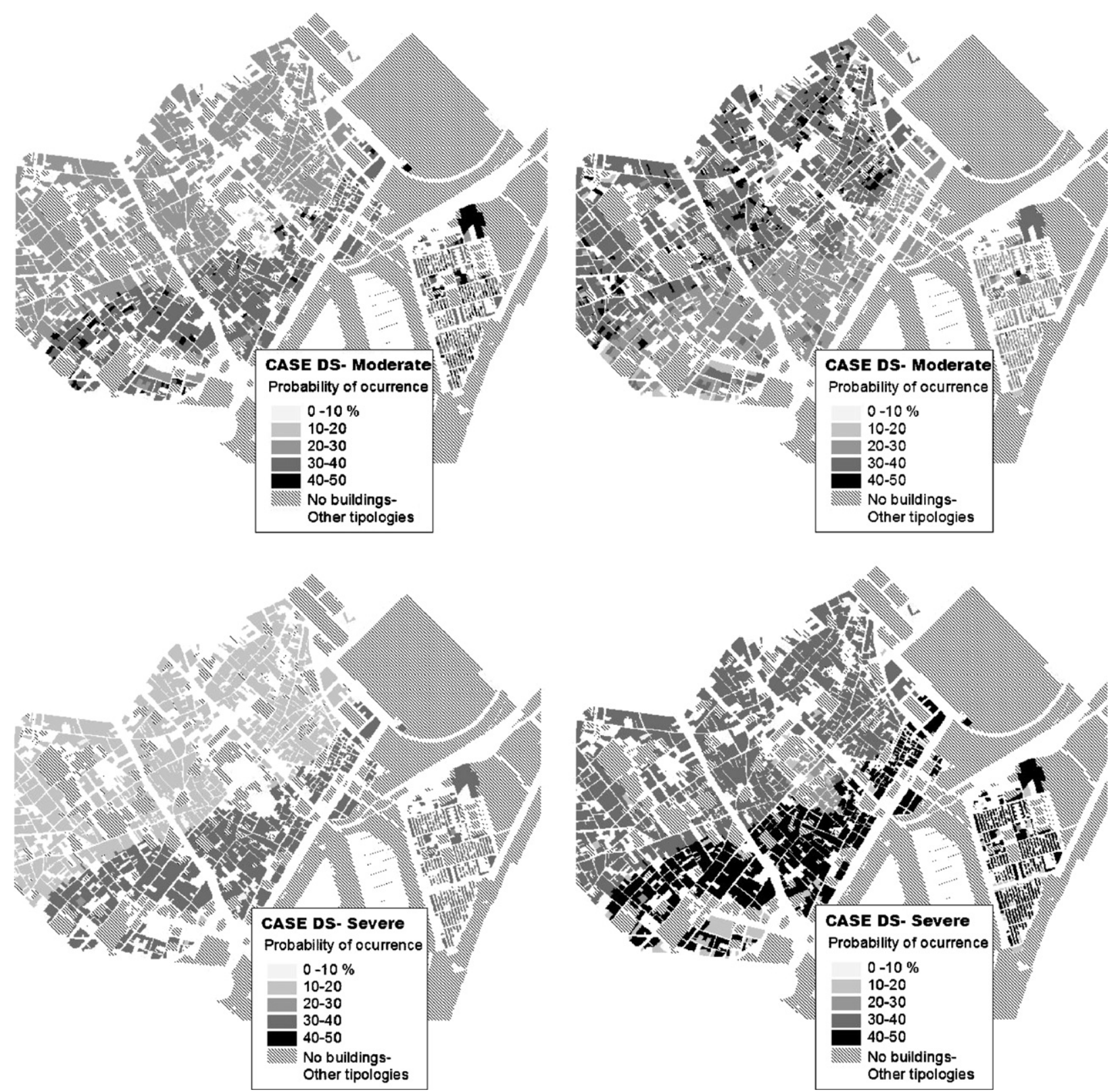

Fig. 12. Probability maps for the damage states moderate (above) and severe (below) for the Ciutat Vella (district 01). Both deterministic (left) and probabilistic (right) seismic scenarios are shown.

\section{Conclusions}

The seismic risk evaluation method used in this paper incorporates last generation methodologies for hazard, damage and risk estimation. It is efficient in coping with the enormous number of buildings existing in modern urban areas. We solved this problem by classifying the buildings in typological groups. The vulnerability of the different building classes is characterized by bilinear capacity spectra obtained by using CMS methods. The basic seismic hazard in the studied area is defined by $5 \%$ elastic response spectra starting from which demand spectra are obtained. The seismic microzonation allows obtaining specific elastic response and demand spectra for the different soil types of the urban area. Starting from capacity spectra, fragility curves are also estimated in a simplified way for each considered building type. Fragility curves are used to characterize the expected structural damage in a probabilistic way. Together with the performance of the building when submitted to a specific seismic action, they lead to damage probability matrices for each seismic zone which are the key result for calculating seismic risk scenarios.

The adopted method has been applied to Barcelona, which is a typical Mediterranean city, located in a lowto-moderate seismic hazard area. One of the most important results, which have been obtained, is the seismic vulnerability characterizations of the buildings. Reliable capacity curves have been thus obtained, which show a wide vulnerability range for both the masonry and the 

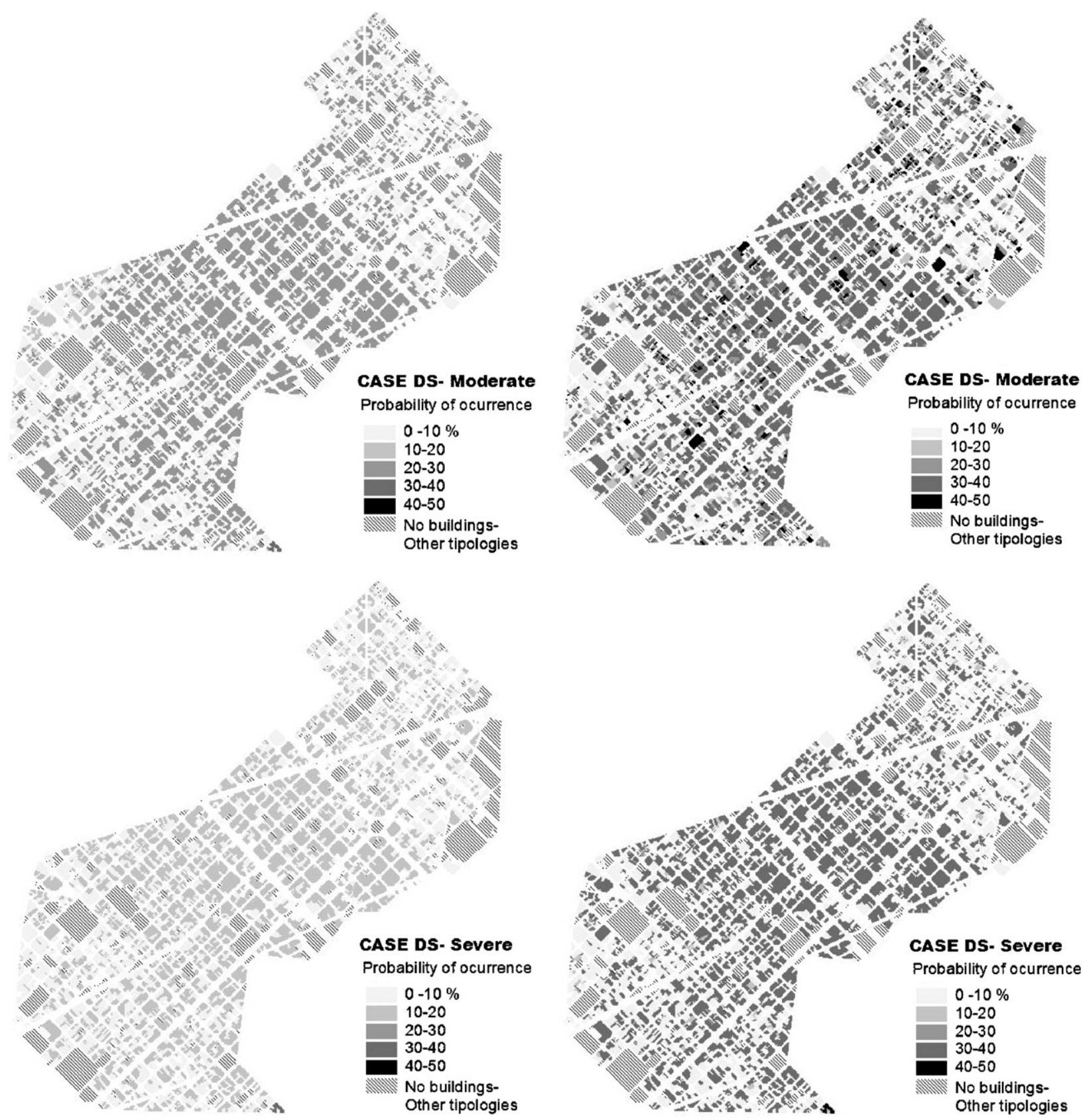

Fig. 13. Probability maps for the damage states moderate (above) and severe (below) for the Eixample district. Both deterministic (left) and probabilistic (right) seismic scenarios are shown.

reinforced concrete buildings. Capacity and fragility curves have been developed for about $97 \%$ of the residential building stock of the city, which is well represented by six building classes. Credible hazard scenarios in ADRS format have been used for the studied urban area. Significant damage is obtained for mid-rise and high-rise masonry buildings, due to the slenderness and low strength of these buildings. Reinforced concrete buildings with waffle slabs also show low seismic capacity leading to significant expected damage. Damage probability matrices have been obtained for the four seismic areas of the city, allowing development of representative risk scenarios, which are based on a complete and highly reliable database for the buildings of the city. Seismic risk scenarios have been developed based on a building-by-building analysis. These physical damage scenarios have been mapped according to different territorial or political areas of the city like districts, neighborhoods and census zones. They constitute excellent information sources and tools for risk management, emergency planning and also useful for civil protection, prevention and preparedness.

\section{Acknowledgments}

This work has been partially sponsored by the Spanish Ministry of Education and Science and with FEDER funds 
(Projects: REN2002-03365/RIES, REN2003-07170/RIES and CGL2004-22325-E, CGL-2005-04541-C03-02/BTE) and by the European Commission (RISK-UE Project, contract EVK4-CT-2000-00014).

\section{References}

[1] Benedetti D, Petrini V. Sulla vulnerabilit. L'industria delle Construzioni 1984;149:66-74.

[2] ATC-13. Earthquake damage evaluation data for California. Redwood City, CA: ATC Applied Technology Council; 1985.

[3] HAZUS 99-SR2. HAZUS technical manual, vols. 1-3. Washington, DC: Federal Emergency Management Agency, FEMA \& National Institute of Building Sciences, NIBS; 2002.

[4] Kappos A, Pitilakis K, Stylianidis K, Morfidis K. Cost-benefit analysis for the seismic rehabilitation of buildings in Thessaloniki, based on a hybrid method of vulnerability assessment. In: Proceedings of the 5th international conference on seismic zonation, Nice, 1995, vol. 1. p. 406-13.

[5] Singhal A, Kiremidjian AS. Method for probabilistic evaluation of seismic structural damage. J Struct Eng ASCE 1996;122(12): 1459-67.

[6] Barbat AH, Yépez Moya F, Canas JA. Damage scenarios simulation for seismic risk assessment in urban zones. Earthquake Spectra 1996;12(3):371-94.

[7] Anagnos T, Rojahn C, Kiremidjian A. NCEER-ATC joint study on fragility of buildings. Report NCEER-95-0003. Buffalo, New York: National Center for Earthquake Engineering Research, 1995.

[8] Milutinovic ZV, Trendafiloski GS. Vulnerability of current buildings. Work Package 4 of RISK-UE Project. European Commission, EVK4-CT-2000-00014, 2003.

[9] Barbat AH, Pujades LG, Lantada N. Performance of buildings under earthquake in Barcelona, Spain. Comput-Aided Civil Infrastruct Eng 2006;21:573-93.

[10] Barbat AH, Lagomarsino S, Pujades LG. Vulnerability assessment of dwelling buildings. In: Oliveira CS, Roca A, Goula X, editors. Assessing a managing earthquake risk. Dordrecht, The Netherlands: Springer; 2006. p. 115-34 [Chapter 6].

[11] Moreno R, Bairán JM, Pujades LG, Aparicio AC, Barbat AH. Evaluación probabilista del comportamiento de edificios porticados de hormigón armado. Hormigon y acero 2004;232:125-36.

[12] Barbat AH, Mena U, Yépez F. Evaluación probabilista del riesgo sísmico en zonas urbanas. Revista internacional de métodos numéricos para cálculo y diseño en ingeniería 1998;14:247-68.

[13] Carreño ML, Cardona OD, Barbat AH. Urban seismic risk evaluation: a holistic approach. Nat Hazards 2007;40:137-72.

[14] Carreño ML, Cardona OD, Barbat AH. Disaster risk management performance index. Nat Hazards 2007;41:1-20.

[15] Freeman SA. Prediction of response of concrete buildings to severe earthquake motion. In: Proceedings of Douglas McHenry international symposium on concrete and concrete structures, Publication SP-55. Detroit, MI, USA: American Concrete Institute, 1978.

[16] Freeman SA. The capacity spectrum method. In: Proceedings of the 11 th European conference on earthquake engineering, Paris, 1998.

[17] Fajfar P. A non linear analysis method for performance-based seismic design. Earthquake Spectra 2000;16(3):573-5924.

[18] Fajfar P. Structural analysis in earthquake engineering - a breakthrough of simplified non-linear methods. In: Proceedings of the 12th European conference on earthquake engineering, London, 2002.

[19] Egozcue JJ, Barbat A, Canas JA, Miquel J, Banda E. A method to estimate intensity occurrence probabilities in low seismic activity regions. Earthquake Eng Struct Dyn 1991;20:43-60.

[20] Calvi GM, Magenes G, Bommer JJ, Pinho R, Crowley H, RestrepoVélez LF. Displacement-based methods for seismic vulnerability assessment at variable geographical scales. ISET J Earthquake Technol 2006;43(3):75-104.
[21] Faccioli E. Seismic hazard assessment for derivation of earthquake scenarios in Risk-UE. Bull Earthquake Eng 2006;4(4):341-64.

[22] Gambarotta L, Lagomarsino S. A microcrack damage model for brittle materials. Int J Solids Struct 1993;30:177-98.

[23] Carr A. Inelastic dynamic analysis program: RUAUMOKO and post-processor for RUAUMOKO. New Zealand: Department of Civil Engineering, University of Canterbury; 2000.

[24] ATC-40, Seismic evaluation and retrofit of concrete buildings. Applied Technology Council, Report: SSC 96-01, vol. 1. Redwood City, CA: Seismic Safety Commission, 1996.

[25] Grünthal G, editor. European Macroseismic Scale 1998, vol. 15. Luxemburg: Centre Européen de Géodynamique et Séismologie, Cahiers du Centre Européen de Géodynamique et de Séismologie; 1998.

[26] Infocca. Funcions d'informació de Barcelona i Cartografia. IMI, Ajuntament de Barcelona, 1999.

[27] Departament d'Estadística. Anuari estadístic de la ciutat de Barcelona 2002. Departament d'Estadística. Ajuntament de Barcelona. Barcelona, 2002.

[28] PGS-1. Norma Sismorresistente P.G.S.-1, Comisión Interministerial de la Presidencia del Gobierno, Decreto 106/1969 de 16 de enero de 1969, 1968.

[29] Lungu D, Aldea A, Arion A, Vacareanu R, Petrescu F, Cornea T. European distinctive features, inventory database and typology, Work Package 1 of RISK_UE Project. European Commission, EVK4-CT-2000-00014, 2001.

[30] Irizarry J, Goula X, Susagna T. Analytical formulation for the elastic acceleration-displacement response spectra adapted to Barcelona soil conditions. Technical Report. Barcelona: Institut Cartogràfic de Catalunya, 2003.

[31] Irizarry J. An advanced approach to seismic risk assessment. Application to the cultural heritage and the urban system of Barcelona. Ph.D. thesis. Barcelona: Universitat Politècnica de Catalunya, 2004.

[32] Goula X, Susagna T. Observation, characterization and prediction of strong ground motion. In: Oliveira CS, Roca A, Goula X, editors. Assessing a managing earthquake risk. Dordrecht, The Netherlands: Springer; 2006. p. 47-65 [Chapter 3].

[33] Roca A, Oliveira CS, Ansal A, Figueras S. Local site effects and microzonation. In: Oliveira CS, Roca A, Goula X, editors. Assessing a managing earthquake risk. Dordrecht, The Netherlands: Springer; 2006. p. 67-89 [Chapter 4].

[34] Faccioli E, Pessina V. Use of engineering seismology tools in ground shacking scenarios. In: Lee WHK, Kanamori H, Jennings P, Kisslinger $\mathrm{C}$, editors. International handbook of earthquake and engineering seismology, Part B (International Geophysics). Academic Press; 2002. p. 1031-49.

[35] Rey J, Faccioli E, Bommer J. Derivation of design soil coefficient (S) and response spectral shapes for Eurocode 8 using the European Strong-Motion Database. J Seismol 2002;6(4):547-55.

[36] Olivera C, Redondo E, Lambert J, Riera Melis A, Roca A. Els terratrèmols del segles XIV i XV a Catalunya. Barcelona: Institut Cartogràfic de Catalunya, Generalitat de Catalunya; 2006.

[37] Cid J. Zonificación sísmica de la ciudad de Barcelona basada en métodos de simulación numérica de efectos locales. Ph.D. thesis. Barcelona, Spain: Technical University of Catalonia, 1998.

[38] Cid J, Susagna T, Goula X, Chavarria L, Figueras S, Fleta J, Casas A, Roca A. Seismic zonation of Barcelona based on numerical simulation of site effects. Pure Appl Geophys 2001;158:2559-77.

[39] Bommer JJ, Abrahamson NA. Why do modern probabilistic seismic hazard analyses often lead to increased hazard estimates? Bull Seismol Soc Am 2006;96(6):1967-77.

[40] Oliveira CS, Campos-Costa A. Overview on earthquake hazard assessment-methods and new trends. In: Oliveira CS, Roca A, Goula X, editors. Assessing a managing earthquake risk. Dordrecht, The Netherlands: Springer; 2006. p. 15-46 [Chapter 2].

[41] Galaso A, Lagomarsino S, Penna A. TREMURI Program: seismic analysis of 3D masonry buildings. Italy: University of Genoa; 2002. 